\title{
INDONESIA ZERO EMISSIONS APPLICATION (EMISI): METHODOLOGY FOR CALCULATING INDIVIDUAL EMISSIONS FROM FOOD, CLOTHING, ELECTRICITY CONSUMPTION, AND SOLID WASTE
}

DEWI SARI, MUHAMAD RIZKI, BENITA NATHANIA, MUMTAZ AHMAD, PHILIPE GUNAWAN GAN, AND NANDA NOOR

\section{EXECUTIVE SUMMARY}

Humans' daily household activities-such as cooking, heating or cooling, and using electric appliancesaccelerate the climate crisis and risk public health by producing substantial greenhouse gas (GHG) emissions and air pollutants. Meanwhile, a global survey emphasized that Indonesia is among the countries with the highest population of climate change deniers, at 18 percent (Hilman and Harvey 2019). Therefore, it is crucial to establish a locally relevant and practically accessible platform that can educate and empower Indonesians to mitigate their households' contribution to climate change.

The Indonesia Zero Emissions Application (EMISI) was developed in 2020 to help the public and organizations easily calculate and track emissions associated with land transportation activity in Indonesia. However, a calculation method for household activity-based emissions in an Indonesia-specific environment is not yet available. Serving as technical guidance for EMISI, this Technical Note aims to extend the current EMISI platform's calculator method beyond land transport emission and into household emissions, which includes consumption of food, clothing, electricity, and waste.

The EMISI application calculates food and clothing waste as the most common household waste types for short-to-medium time frames. A bottom-up approach is used to calculate the associated GHG emissions and/ or air pollutants, resulting in personalized, sciencedriven, and trackable quantitative estimates. To ensure accountability and precision of calculations within EMISI, the methodology is adopted from the Intergovernmental Panel on Climate Change (IPCC). Emission factors used in the methodology are generated from various notable and peer-reviewed Indonesian and international studies.

\section{CONTENTS}

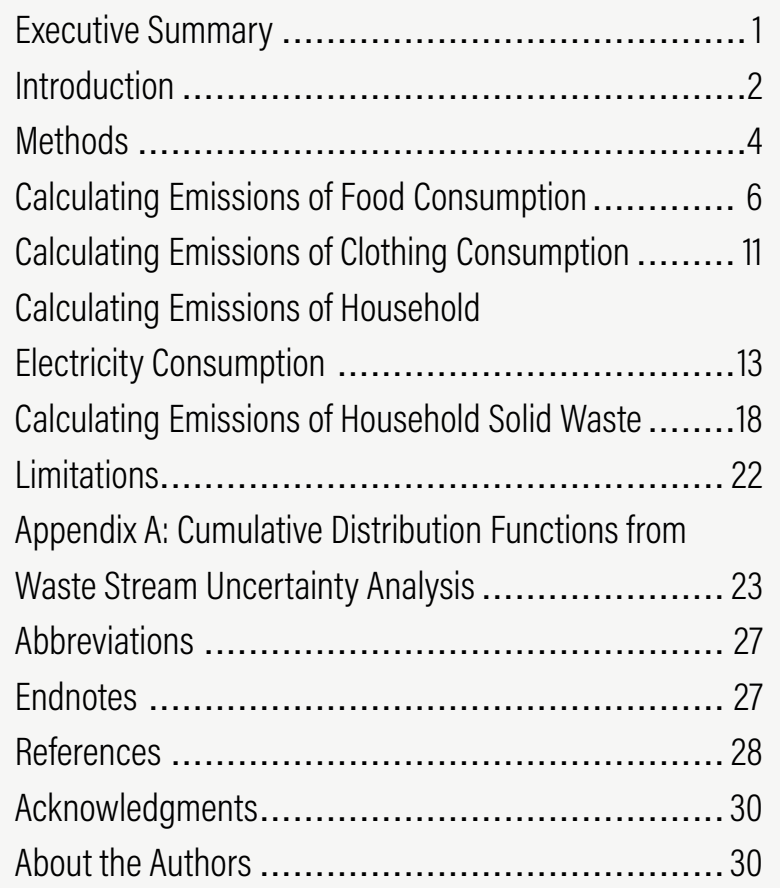

WRI Technical Notes document methodology underpinning research publications, interactive applications, and other tools.

Suggested Citation: Sari, D., M. Rizki, B. Nathania, M. Ahmad, P.G. Gan, N. Noor. 2021. "Indonesia Zero Emissions Application (EMISI): Methodology for Calculating Individual Emissions from Food, Clothing, Electricity Consumption, and Solid Waste" Technical Note. Jakarta, Indonesia: World Resources Institute. Available online at: https://doi.org/10.46830/writn.20.00095. 
The methodology documented in this Technical Note can be adopted by various stakeholders in Indonesia, including government, nongovernmental and private organizations, scientific experts, communities, and public individuals. This Technical Note aims to provide an accountable and robust methodology that such stakeholders could easily apply to their systems (i.e., employee/customer emission management) or platforms (i.e., websites or mobile applications), including to develop their own emission calculators. Furthermore, data resulting from calculations derived from this Technical Note could also help improve Indonesia's emissions inventory knowledge at the individual level, as well as add value to other research and development activities. While this Technical Note provides estimates using the best available data and modeling, some limitations-such as the unavailability of updated emission factors-underline that continuous improvement of the method is needed when more Indonesian-specific data and studies become available.

\section{INTRODUCTION}

The EMISI application was developed in response to Indonesians' need to simplify their climate changerelated actions. Initially launched nationwide in August 2020, EMISI aims to enable Indonesians to learn, measure, track, and act on how their lifestyle impacts climate change through high-quality emissions calculation, reduction, and sequestration at the personal level (Rizki et al. 2020). As shown in Figure 1, the current application only allows users to calculate the emissions produced from their land transport activities, while daily consumption of food, clothing, and electricity also produce significant emissions and pollution.

These household consumption activities significantly contribute to accelerating global climate change compared to other sources, at 72 percent (Hertwich and Peters 2009). This condition is predicted to increase following the steady growth of world population, which leads to more consumption at the household level (O'Neill et al. 2010). Moreover, the global COVID-19 pandemic, which was occurring during this study, has pushed more people to stay home more often, consequently increasing household consumption even further. E-shopping (for food or daily supplies) and electricity consumption are among the emissions-generating activities that rise the most, as people opt to participate in home-based activities (i.e., for working, studying, leisure, etc.) (Bulut 2020; Rahman 2021).
While these lifestyle behaviors help prevent disease transmission and keep the economy running, their environmental impact should not be overlooked. Mobility and transportation activities may have been less intense during the physical distancing periods, thus emissions and air pollutants released might have been reduced. However, this situation may instead increase emissions produced at home. Hence, this calls for EMISI to enable its users to measure and track their emissions from lifestyle, including food, clothing, and electricity consumption, as well as waste resulting from such household activities.

This Technical Note describes the underlying methodology used in EMISI to calculate household emissions, as an extension of land transport emissions. The methodology follows the notable bottom-up approach used by the Intergovernmental Panel on Climate Change (IPCC) to calculate greenhouse gases (GHGs) and air pollutant emissions (IPCC 1991, 2006) and considers the life cycle process (Poore and Nemecek 2018; Curran 2017). Nonetheless, with the complex and unique characteristics of emissions and pollutants produced in each sector, this Technical Note has its limitations. The method calculates $\mathrm{CO}_{2} \mathrm{e}$ for the clothing and food sectors, $\mathrm{CO}_{2}$ emissions and air pollutants $\left(\mathrm{SO}_{2}\right.$ and $\mathrm{NO}_{\mathrm{x}}$ ) for electricity use, and $\mathrm{CO}_{2}, \mathrm{CH}_{4}$, and $\mathrm{N}_{2} \mathrm{O}$ for the waste sector. By including these calculations, EMISI aims to educate more people about the impact of individual consumption behavior on climate change and empower people to take even more actions to reduce their climate footprint. EMISI integrates and accumulates the collected emissions tracking data for further research and development purposes, aiming to provide a variety of transparent, science-based emission facts (transport, food, clothing, electricity, and waste) derived from individuals' lifestyles in households.

Like land transport and mobility emissions, household emissions have also been calculated by various government agencies and multinational companies in Indonesia and abroad, though often segregated by sector. The EMISI application, however, aims to integrate food, clothing, electricity, and waste emissions into one framework and methodological approach that is specific to Indonesia's context, such as for its emission factors. 

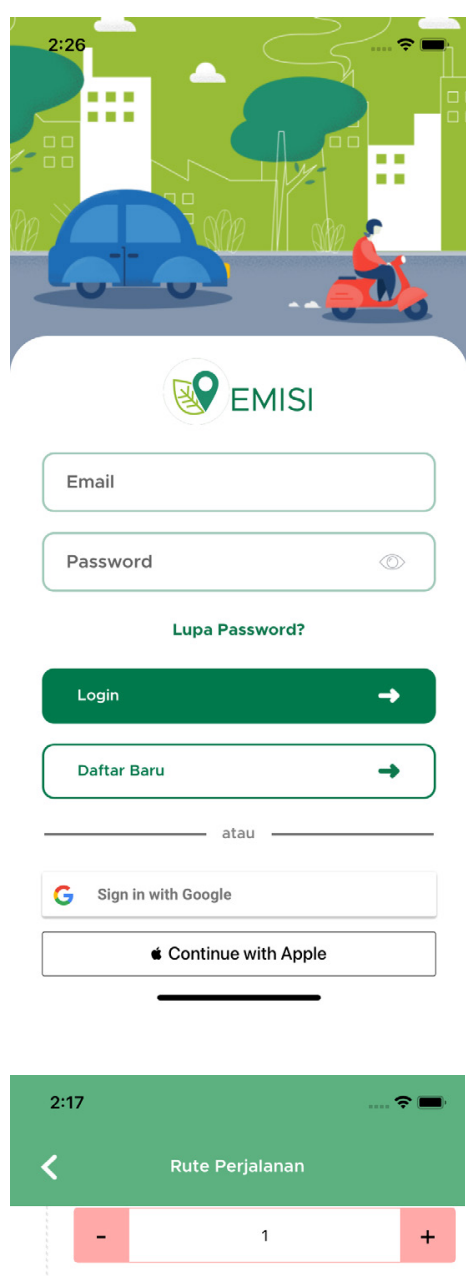

(i) Jalan ramai-ramai lebih seru dan lebih rendah emisi, loh! Jadi, kalau kamu paka mobil pribadi jangan lupa ajak temantemanmu. Kalau pakai motor, jangan lupa ajak berboncengan, ya!

Jl. Wijaya I No.63, RT.8/RW.1, Petogogan, Kec. Kby. Baru, Kota Jakarta Selatan, Daerah Khusus Ibuk...

Tambah Rute Perjalanan

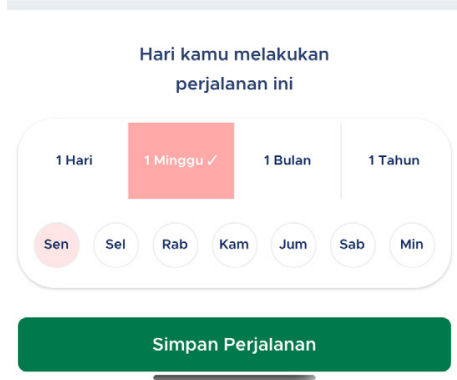

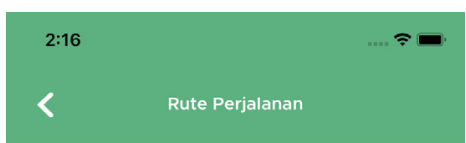

The River Fontana B6 67, Parung Panjang, Bogor, West Java 16360, Indonesia

MOBIL - UBAH
JARAK: $1.40 \mathrm{~km}$

(i) Kamu bisa mengurangi emisi dengan memakai angkutan umum.

\section{JENIS KENDARAAN}

Private
kendaraan pribadi
ojek, ojek online, dll

PENUMPANG

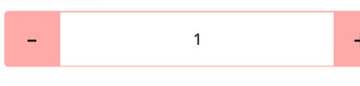

(i) Jalan ramai-ramai lebih seru dan lebih rendah emisi, loh! Jadi, kalau kamu paka mobil pribad jangan lupa ajak temanajak beronsa pakaim

Parung Panjang Station, Jl. Marga Mekar No.54 16360, Parung Panjang, Bogor, Jawa Barat 16360, Indonesia
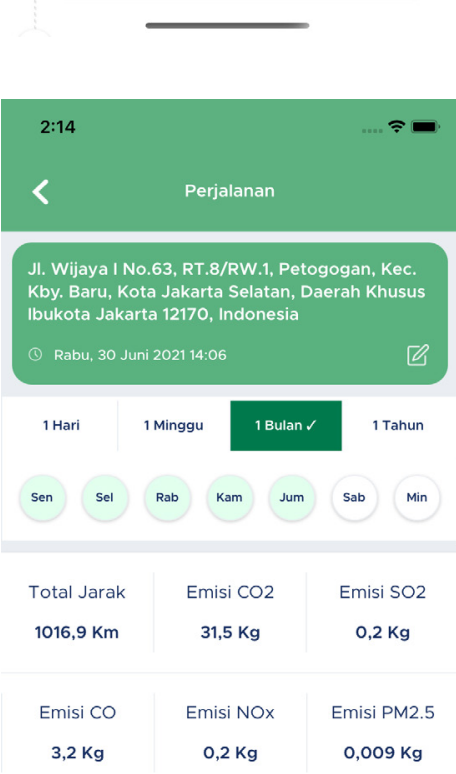

$\begin{array}{llll}3,2 \mathrm{~kg} & 0,2 \mathrm{Kg} & 0,009 \mathrm{~kg}\end{array}$

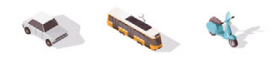

\section{Lihat Detil Perjalanan}

Persentase Emisi Tiap Kendaraan

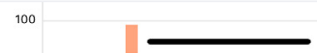

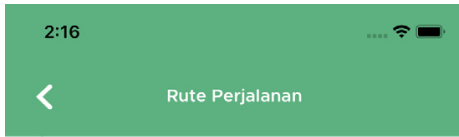

Parung Panjang Station, J. Marga Mekar No.54 16360, Parung Panjang, Bogor, Jawa Barat 16360 , Indonesia

kereta - Ubah

JARAK: $34.50 \mathrm{Km}$

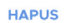

(i) Terima kasih, kamu telah memilih mode transportasi yang rendah emisi.

Stasiun Tanahabang, Jalan Jati Baru Raya, Jl. Cideng Timur, Kp. Bali, Kecamatan Tanah Abang, Kota Jaka...
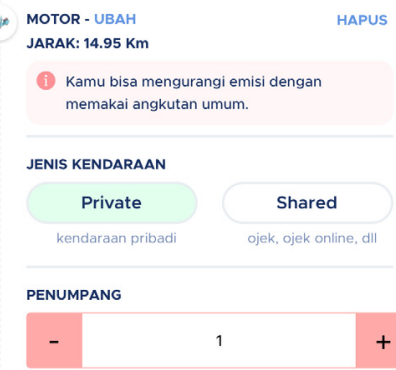

i. Jalan ramalramarteoris serudan lebih
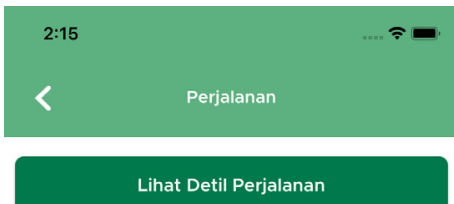

Lihat Detil Perjalanan

Persentase Emisi Tiap Kendaraan

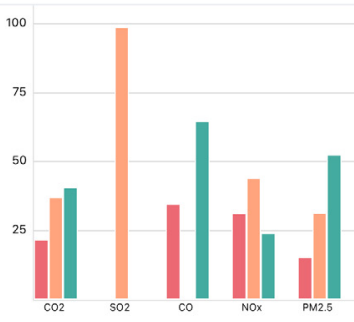

Terima kasin ya! kalau bisa makin sering yah naik angkutan umumnya. Tapi kalau masih perlu naik angkutan pribadi kamu juga bisa menyerap emisimu dengan menanam pohon

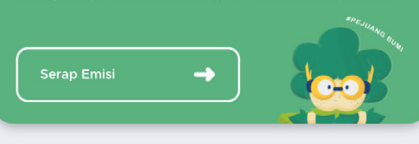

Users need to log in and input transport activities, including location and mode of transport. Then EMISI will measure the emission numbers, followed by options for how to reduce and sequester these. 


\section{METHODS}

The methods in this Technical Note build upon the preceding EMISI Technical Note for land transport emissions calculation (Rizki et al. 2020) by adding a household emissions calculation. EMISI is developed based on similar, existing carbon footprint calculators and frameworks, such as the EPA Carbon Footprint Calculators (EPA 2015, 2020), the GHG Protocol (Fong et al. 2014), and the IPCC Framework (IPCC 2006) to calculate GHGs and air pollutant emissions. To ensure accountability and precision, the estimates are generated from notable and various international and Indonesiaspecific peer-reviewed papers. This study then classifies household emissions based on three different sources: food, clothing, and electric appliances. Moreover, it also estimates emissions coming from waste due to individual consumption. Some complications exist regarding the lifestyle emissions calculation because of the long lifecycle process (from production to waste).
Figure 2 explains the classification and stages of food, clothing, and electricity usage as sources of emissions from household activities. The far-left column represents the stage where emissions occur and are calculated (i.e., production, consumption, and waste). On the one hand, the emissions released from the consumption of clothing and food are calculated within their production and waste stages. On the other hand, as the name suggests, electricity use emissions are limited to calculation of appliances' energy consumption and waste, excluding emissions from production of the appliances themselves. In addition, other household consumptions (i.e., food scraps, yard waste, clothing, papers, plastics, and others) are calculated in the waste phase post-consumption.

Figure 2 | Scope of Emission Sources Calculated from Household Activities

\begin{tabular}{|c|c|c|c|c|}
\hline \multirow{2}{*}{ Stage } & \multicolumn{4}{|c|}{ Household Emission Sources } \\
\cline { 2 - 5 } & Clothing & Food & Appliances & Others \\
\hline Production & $\sqrt{ }$ & $\sqrt{ }$ & $\mathrm{X}$ \\
\hline Consumption & $\mathbb{X}$ & $\mathrm{X}$ & $\sqrt{ }$ \\
\hline Waste* & $\sqrt{ }$ & $\sqrt{ }$ & $\sqrt{ }$ \\
\hline
\end{tabular}

Note: *after consumption

Source: Authors.

As illustrated in Figure 3, the calculation itself consists of two components for each source, which generally consist of data input and an emission and/or pollutants equation. The following subsection provides an overview of methods for each sector and its associated waste.

\section{Food}

Emissions from food are calculated based on weekly consumption per household, as this is the most common interval by which Indonesians purchase food and beverages. The calculation begins by asking users to input the number of household residents, followed by food type and mass or weight of food per week. This is then multiplied by emission factors corresponding to each food type to estimate the $\mathrm{CO}_{2} \mathrm{e}$ emission for the entire household. Emission factors vary for each food type and are stored in a database. After that, food emission per person is calculated by dividing the total emission per household by the number of household residents.

\section{Clothing}

Emissions from clothing are calculated by asking users to input the quantity of new purchases per garment type whenever they buy new clothing. As each garment type has a different weight (Peters et al. 2015), mass will be used as a variable in calculating emissions. The mass per garment type is then multiplied by the number of new purchases made by users. The total mass will then be multiplied by the emission factor (van der Velden et al. 2014) derived from raw material extraction to garment production process (cradle-to-gate). The emission factor will depend on the garment's mix of material to produce the total emissions from each user's clothing consumption. Garment material affects the emission factor (cradle-to-gate) as a multiplier. For example, a shirt made from 100 percent cotton has a greater emission impact than a shirt made from 100 percent polyester (although cotton fabrics are easier to decompose because they are made of natural fiber). 


\section{Electricity}

Emissions from household electricity are calculated by asking users to input the number of residents who utilize electric appliances. As part of the activity-based method calculation requirement (IPCC 2006), data on appliance type (i.e., refrigerator, air conditioning, lamp, laptop, television, etc.) and hours of usage are collected. To calculate $\mathrm{CO}_{2}$ emissions and pollutants (i.e., $\mathrm{NO}_{\mathrm{x}}$ and $\mathrm{SO}_{2}$ ), the calculation combines data input by users with the emission factor, the electricity consumption factor for each appliance, electricity transmission and distribution losses, the thermal efficiency of the power plant, and the power plant fuel mix from various literature (EPA 2020; NEC 2019; Unbound Solar n.d.; Wijaya and Tezuka 2013; Damayanti and Khaerunissa 2018).

\section{Waste}

Emissions from corresponding waste from each sector are calculated from users' data input on waste mass and its correlated composition. The composition categories are simplified into organic (food scraps and yard waste) and inorganic waste (i.e., clothing, paper, plastic, and others). Emissions from waste disposal is based on the waste processing method used to deplete the waste. After waste mass and composition are identified, the potential waste management systems could be estimated, where users would be required to choose their city characteristic (rural/urban) as EMISI's chosen proxy to portray the difference in waste treatment methods. These would result in the corresponding $\mathrm{CO}_{2}, \mathrm{~N}_{2} \mathrm{O}$, and $\mathrm{CH}_{4}$ emissions from disposal of waste (IFEU 2009).

Figure 3 | Household Emission Calculation Framework

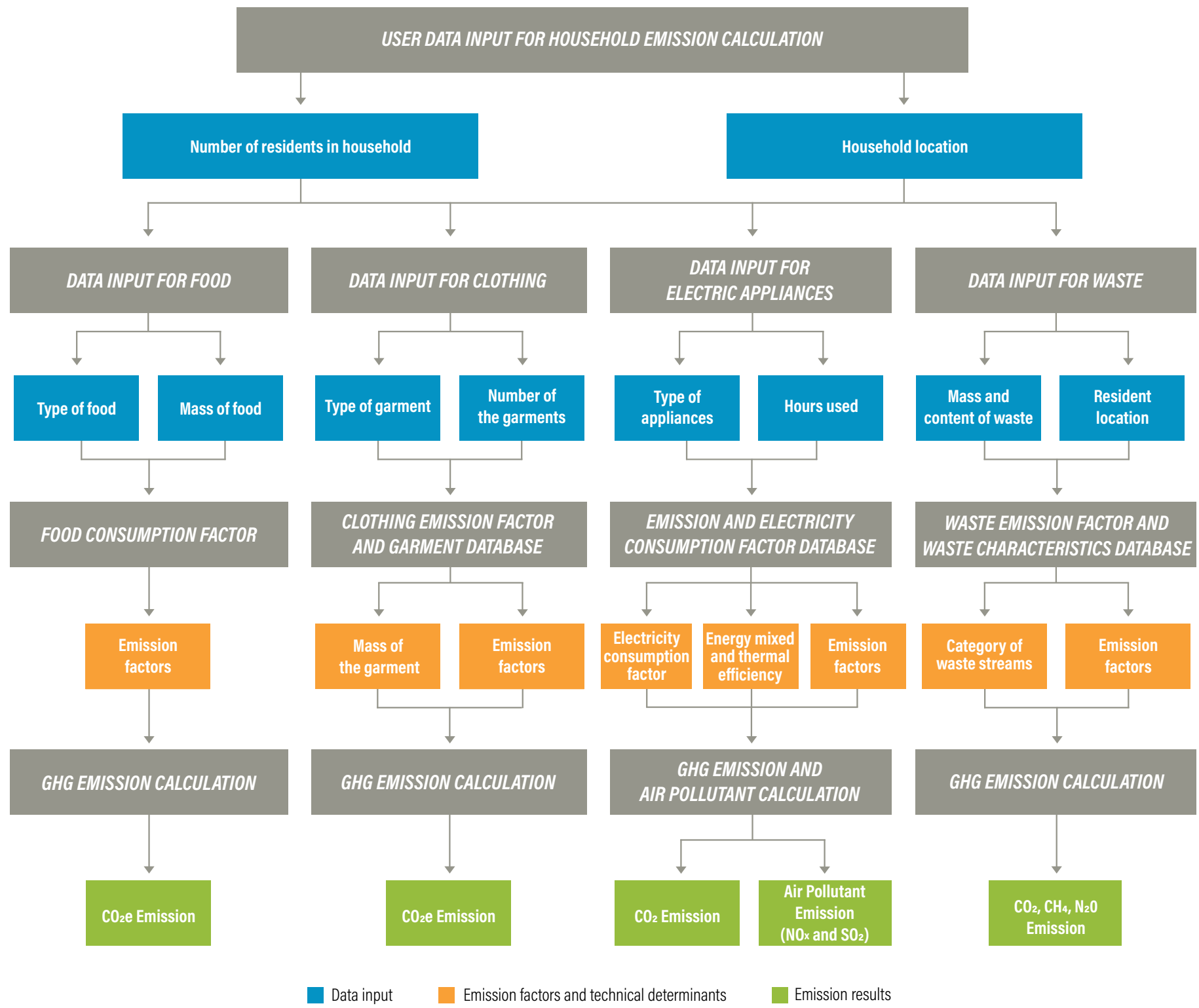


EMISI will allow users to calculate their carbon footprint from each sector and enable users to compare the emission from each type of food purchase, clothing purchase, electrical appliance usage, and waste produce. The comparison may lead users to change their lifestyle choice to one with a smaller carbon footprint.

Below are three scenarios if users change their lifestyle in one sector and comparison of avoided emission to another sector.

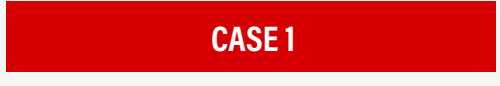

IF A USER CHANGES THEIR FOOD FROM

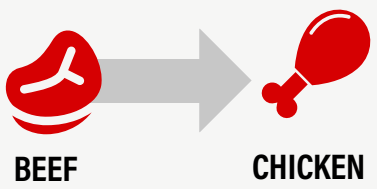

WILL AVOID

$189.8 \mathrm{KG} \mathrm{CO}_{2} \mathrm{e}$

WHICH IS EQUAL TO EMISSIONS

FROM PURCHASING

24 TOPS \&

2 NIGHTWEAR

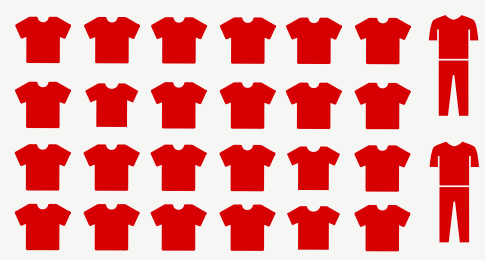

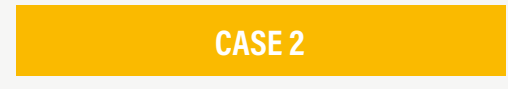

IF A USER CHANGES THEIR FOOD FROM

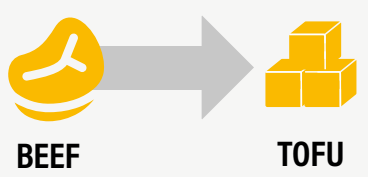

WILL AVOID

204.3 KG CO2

WHICH IS EQUAL TO EMISSIONS

FROM PURCHASING

26 TOPS \&

4 GLOVES

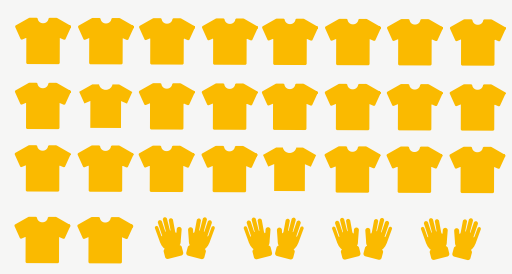

\section{CASE 3}

IF A USER REDUCED THEIR AC USAGE FOR 14.53 HOURS

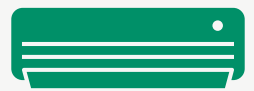

WILL AVOID

\section{$20 \mathrm{KG} \mathrm{CO}_{2}$}

WHICH IS EQUAL TO EMISSIONS

FROM PRODUCING

192.1 KG

OF ORGANIC WASTE

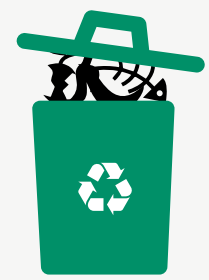

\section{CALCULATING EMISSIONS OF FOOD CONSUMPTION}

Global food production and consumption have driven land and water ecosystem degradation, water scarcity, and climate change (Poore and Nemecek 2018; Cucurachi et al. 2019; Balogh and Jámbor 2020). Food production and consumption emit GHGs $\left(\mathrm{CO}_{2} \mathrm{CH}_{4}\right.$, and $\left.\mathrm{N}_{2} \mathrm{O}\right)$, sulphuric compounds ( $\left.\mathrm{SO}_{2} \mathrm{e}\right)$, and phosphoric compounds $\left[\mathrm{PO}_{4}\right]^{3-} \mathrm{e}$, which drive climate change, terrestrial acidification, and aquatic ecosystem eutrophication, respectively. At the same time, excessive use of water and land resources lead to water and forest depletion (Poore and Nemecek 2018).
A Life Cycle Assessment (LCA) is widely used to assess a product's overall environmental impact, from its production to final consumption-in other words, from cradle to grave (Roy et al. 2009; Poore and Nemecek 2018; Cucurachi et al. 2019). For the food emission category, this Technical Note focuses on estimating GHG emissions from food production by compiling studies conducted for diverse food products in Indonesia and other countries. Using LCA, the global food system would emit between $10.8 \mathrm{GtCO}_{2} \mathrm{e}$ and $18.1 \mathrm{GtCO}_{2} \mathrm{e}$, which accounts for 22-37 percent of global anthropogenic emissions (UNEP 2020; Rogissart et al. 2019). 
LCA can be used specifically to calculate climate impacts standardized under ISO 14064 (ISO 2018). This standard has classified LCA method by four major stages (Cucurachi et al. 2019):

1. The definition of goal and scope: this involves defining the purpose, question and question context of study, the limits and boundaries of the system considered, and the functional unit used ( $\mathrm{kg}$, ha, protein, etc.) at the product level.

2. Life Cycle Inventory (LCI): this involves data collection, relationship identification, and input and output quantification for the system as defined in stage 1.

3. Life Cycle Impact Assessment (LCIA): involves accounting the climate change impact in different life cycle phases, which is translated in the same unit. The impact score can be normalized internally or externally.

4. Interpretation: interpret results into useful and accessible conclusions for decision-makers.
Different studies have used LCA to estimate climate impact at the product level, yet results vary by location. These disparities can be caused by inconsistently defined study scopes (Rogissart et al. 2019; Cucurachi et al. 2019). Most LCA studies for food products stop at the farm gate, while the assessment of food products from cradle-to-plate and cradle-to-grave are considerably less prevalent (Rogissart et al. 2019). This is explained by variability in post-farm emissions (depending on transport type used) and by the strong influence of consumer behavior on emissions in the post-sales stage (Röös et al. 2014).

Figure 4 shows several possible scopes of productlevel LCA. Scope selection is explained by variability in post-farm emissions, such as the transport type used to distribute food to consumers and variability in consumer behavior in the post-sales stage (Röös et al. 2014). This Technical Note estimates emissions of food products from production to retail.

\section{Figure 4 | Food Life Cycle Scopes Often Used to Estimate Environmental Impact of Food Production and Consumption}

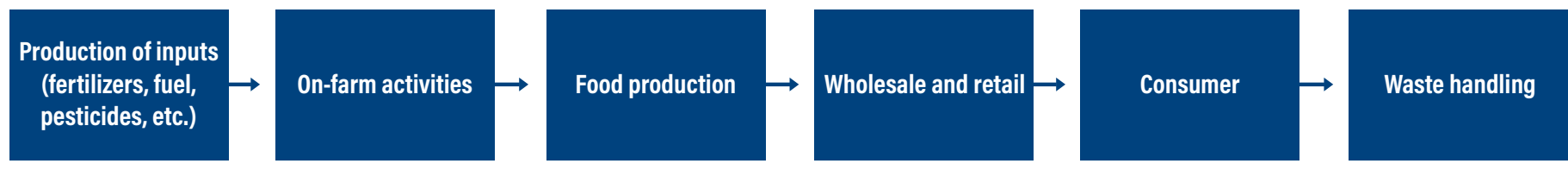

Cradle-to-farm gate

Cradle-to-retail

Cradle-to-plate

Full life cycle of food (or cradle-to-grave)

Source: Rogissart et al. 2019. 
Moreover, variability or disparities in LCA results can be partly caused by different practices of food production and consumption of a product. This can be controlled by using the same practice typologies for the same product. Like any method to estimate GHG emissions, LCA results are characterized by uncertainty and can be originated from emission factors. Also, the difference in methods pertaining to modeling of direct and indirect land use change (LUC) often emerge (Rogissart et al. 2019). In this Technical Note, the estimation of carbon footprint using the LCA method conducted by several studies includes the LUC impact, hence the emission estimation is presented with a wide results range.

A study by Poore and Nemecek (2018) consolidated data on multiple environmental impacts using LCA models to estimate carbon footprint from the food system and to find discrepancy in LCA results and balances in emission estimation. This study used 38,000 farm cases that produced 40 different food types around the world to estimate its carbon footprint. This technical note uses the averaged carbon footprint calculated by the Poore and Nemecek (2018) study as the emission factors in the EMISI application.

EMISI calculates GHG emissions from individual food consumption based on user data input. These data consist of food type, food mass consumed per food type, and number of household residents consuming the food. The formula to calculate $\mathrm{GHG}$ emissions $\left(\mathrm{CO}_{2} \mathrm{e}\right)$ for individual food consumption is:

Total food emission per person $\left(T F E P_{p}\right)=\sum_{i=1}^{N} \frac{M_{i}}{P_{i}} x E F_{i}$ (1)

where $i(i=1,2, \ldots N)$ is food type $\left(i^{t h}\right) ; M_{i}$ is mass of food type $(\mathrm{kg})$ per household; and $P_{i}$ is number of residents per household. $E F_{i}$ is emission factors for $\mathrm{GHG}\left(\mathrm{CO}_{2} \mathrm{e}\right)$ based on food type (i). The total food consumption per person is the sum of the total emissions produced per $\mathrm{kg}$ of food multiplied by emission factor.

\section{The Determinants of Food Emission Factors}

The emission factors per food type are presented in Table 1 . The mean, $5^{\text {th }}-95^{\text {th }}$ percentile range, and $90^{\text {th }}$ percentiles for these emission factors are generated based on the average emission of each food type across global LCA studies, which estimate GHG emissions with climate carbon feedback (IPCC characterization factors), as compiled by Poore and Nemecek (2018). For each food type, the emission factor used is at $9 \mathrm{O}^{\text {th }}$ percentiles, to ensure the results are not underestimated, as the emission range from food product is wide enough. Table 1 also shows that emissions released for different food types vary considerably, meaning that the choice of food type consumed significantly influences the emissions released from food sectors. The same table also shows that animal-based food generally produces larger emissions than plant-based food. 
Table $\mathbf{1}$ | Emission Factors for Several Food Types Seen from Product-Level LCA Studies

\begin{tabular}{|c|c|c|c|c|c|}
\hline & Food type & Mass/volume function unit & $\begin{array}{l}5^{\text {th }}-95^{\text {th }} \text { percentile of } \\
\text { emission estimation } \\
(\mathrm{kg} \mathrm{CO} \mathrm{e} / \mathrm{kg})\end{array}$ & $\begin{array}{l}\text { Mean of emission } \\
\text { estimation } \\
(\mathrm{kg} \mathrm{CO} 2 \mathrm{~kg})\end{array}$ & $\begin{array}{l}\text { Estimated emission at } 90^{\text {th }} \\
\text { percentile used as emission } \\
\text { factors }\left(\mathrm{kg} \mathrm{CO} \mathrm{CO}_{2} \mathrm{e} / \mathrm{kg}\right)\end{array}$ \\
\hline \multirow{6}{*}{$\begin{array}{l}\text { Starch-rich } \\
\text { food }\end{array}$} & Wheat and rye & $1 \mathrm{~kg}$ of bread (variable protein wheat) & $0.7-3.1$ & 1.6 & 2.3 \\
\hline & Maize & $1 \mathrm{~kg}$ of meal (for polenta) & $0.7-3.5$ & 1.7 & 2.3 \\
\hline & Oats & $1 \mathrm{~kg}$ of rolled oats & $0.8-4.3$ & 2.5 & 4.1 \\
\hline & Rice & $1 \mathrm{~kg}$ of full-grain white or brown rice & $1.2-10.3$ & 4.5 & 8.8 \\
\hline & Potatoes & $1 \mathrm{~kg}$ of soil-free tuber & $0.1-0.7$ & 0.5 & 0.6 \\
\hline & Cassava & $1 \mathrm{~kg}$ of soil-free tuber & $0.3-2.2$ & 1.3 & 2.1 \\
\hline \multirow{13}{*}{$\begin{array}{l}\text { Protein-rich } \\
\text { food }\end{array}$} & Peas & $1 \mathrm{~kg}$ of dry pea without pod & $0.5-1.9$ & 1.0 & 1.7 \\
\hline & Other pulses & $1 \mathrm{~kg}$ of dry pulse without pod & $0.9-4.0$ & 1.8 & 3.8 \\
\hline & Nuts & $1 \mathrm{~kg}$ of shell-free, dry nut & $-4.0-10.8$ & 0.4 & 3.8 \\
\hline & Groundnuts & $1 \mathrm{~kg}$ of shell-free, roasted nut & $1.4-6.2$ & 3.2 & 5.8 \\
\hline & Tofu & $1 \mathrm{~kg}$ of tofu ( 16\% protein) & $1.4-7.3$ & 3.2 & 5.6 \\
\hline & Cheese & $1 \mathrm{~kg}$ of cheese & $10.2-58.8$ & 23.9 & 39.3 \\
\hline & Eggs & $1 \mathrm{~kg}$ of eggs & $2.9-8.5$ & 4.7 & 8.4 \\
\hline & Poultry meat & \multirow{4}{*}{$\begin{array}{l}1 \mathrm{~kg} \text { of fat and bone-free meat } \\
\text { and edible offal }\end{array}$} & $4.0-20.8$ & 9.9 & 20.1 \\
\hline & Pig meat & & $6.9-23.8$ & 12.3 & 22.3 \\
\hline & Lamb and mutton & & $23.7-60.2$ & 40.6 & 54.4 \\
\hline & Beef & & $37.6-269.2$ & 99.5 & 209.9 \\
\hline & Fish (farmed) & $1 \mathrm{~kg}$ of edible fish & $5.4-32.6$ & 13.6 & 26.5 \\
\hline & $\begin{array}{l}\text { Crustaceans } \\
\text { (farmed) }\end{array}$ & $\begin{array}{l}1 \mathrm{~kg} \text { of head-free meat } \\
\text { (shell-free for large shrimp) }\end{array}$ & $7.4-115.1$ & 26.9 & 52.1 \\
\hline \multirow{4}{*}{ Beverages } & Barley & 1 liter of beer & $0.6-1.8$ & 1.2 & 1.6 \\
\hline & Wine grapes & 1 liter of wine & $0.7-4.7$ & 1.8 & 2.7 \\
\hline & Milk & $\begin{array}{l}1 \text { liter of pasteurized milk } \\
\text { (4\% fat, 3.3\% protein) }\end{array}$ & $1.5-7.0$ & 3.2 & 4.8 \\
\hline & Soybean milk & 1 liter of soymilk ( 3.3\% protein) & $0.5-1.7$ & 1.0 & 1.5 \\
\hline \multirow{9}{*}{$\begin{array}{l}\text { Fruit and } \\
\text { vegetables }\end{array}$} & Berries and Grapes & \multirow{7}{*}{$1 \mathrm{~kg}$ of fresh fruit or vegetable } & $0.6-2.9$ & 1.5 & 2.7 \\
\hline & Bananas & & $0.6-1.3$ & 0.9 & 1.2 \\
\hline & Apples & & $0.3-0.6$ & 0.4 & 0.6 \\
\hline & Citrus fruit & & $0.0-0.7$ & 0.4 & 0.6 \\
\hline & Tomatoes & & $0.4-12.6$ & 2.1 & 6.0 \\
\hline & $\begin{array}{l}\text { Brassicas } \\
\text { (cabbages) }\end{array}$ & & $0.2-1.2$ & 0.5 & 1.0 \\
\hline & Onions and leeks & & $0.3-0.8$ & 0.5 & 0.8 \\
\hline & Root vegetables & $1 \mathrm{~kg}$ of soil-free tuber & $0.2-0.6$ & 0.4 & 0.6 \\
\hline & Other fruit & & $0.3-3.0$ & 1.1 & 2.9 \\
\hline \multirow{5}{*}{ Oil crops } & Palm oil & \multirow{5}{*}{1 liter of refined/filtered oil } & $2.8-13.1$ & 7.3 & 12.0 \\
\hline & Soybean oil & & $2.2-18.8$ & 6.3 & 13.4 \\
\hline & Olive oil & & $2.1-10.8$ & 5.4 & 7.6 \\
\hline & Rapeseed oil & & $2.2-7.2$ & 3.8 & 4.6 \\
\hline & Sunflower oil & & $2.2-4.9$ & 3.6 & 4.6 \\
\hline \multirow{2}{*}{ Sugar crops } & Cane sugar & \multirow{2}{*}{$1 \mathrm{~kg}$ of raw $/$ refined sugar } & $0.6-5.6$ & 3.2 & 5.1 \\
\hline & Beet sugar & & $1.0-2.6$ & 1.8 & 2.4 \\
\hline \multirow{2}{*}{ Other } & Cocoa & $1 \mathrm{~kg}$ of dark chocolate & $-4.0-257.5$ & 46.7 & 134.7 \\
\hline & Coffee & $1 \mathrm{~kg}$ of ground, roasted beans & $4.4-85.7$ & 28.5 & 84.9 \\
\hline
\end{tabular}

Source: Processed by the authors, based on Poore and Nemecek 2018. 
Table 2 illustrates emissions calculations for three different food consumption scenarios. The first scenario shows a typical meat-eating user who consumes beef and chicken combined with cooking oil, vegetables, and fruits in a week. The emission from this scenario is highest compared to the other two, mainly because emission factors from beef are significantly higher than any other type of food. In the second scenario, the user eats seafood such as prawn, crab, and fish, also combined with cooking oil, vegetables, and fruits in a week. The last scenario demonstrates a typical vegetarian who eats tofu and egg as protein sources, combined with some vegetables and fruits. It is shown that emissions from this scenario are lower than in the second scenario, because emission factors of plantbased food are mostly lower than animal-based food.

Table 2 | Weekly Food Consumption and Emissions Calculation for Three Different EMISI User Scenarios

\begin{tabular}{|c|c|c|c|c|c|c|}
\hline $\begin{array}{l}\text { User } \\
\text { scenario }\end{array}$ & Food type & $\begin{array}{l}\text { No. of household } \\
\text { residents }\end{array}$ & $\begin{array}{l}\text { Food consumption } \\
\text { per household } \\
\text { (kg or L) }\end{array}$ & $\begin{array}{l}\text { Emission factor } \\
\left(\mathrm{kg} \mathrm{CO}_{2} \mathrm{e}\right)\end{array}$ & $\begin{array}{l}\text { Total emission } \\
\left(\mathrm{kg} \mathrm{CO}_{2} \mathrm{e}\right)\end{array}$ & $\begin{array}{l}\text { Total emission per person } \\
\text { (TFEPp) }\left(\mathrm{kg} \mathrm{CO}_{2} \mathrm{E}\right)\end{array}$ \\
\hline & (A) & (B) & (C) & (D) & $(E)=(C) \times(D)$ & $(F)=(E) /(B)$ \\
\hline \multirow{8}{*}{1} & Beef & \multirow{7}{*}{4} & 1 & 209.9 & 209.9 & \multirow{7}{*}{88.65} \\
\hline & Chicken & & 3 & 20.1 & 60.3 & \\
\hline & Rice & & 5 & 8.8 & 44 & \\
\hline & Palm oil & & 2 & 12 & 24 & \\
\hline & Onions and leeks & & 1 & 0.8 & 0.8 & \\
\hline & Milk & & 3 & 4.8 & 14.4 & \\
\hline & Apples & & 2 & 0.6 & 1.2 & \\
\hline & \multicolumn{4}{|l|}{ Total emissions } & 354.6 & \\
\hline \multirow{8}{*}{2} & Crustaceans & \multirow{7}{*}{5} & 2 & 52.1 & 104.2 & \multirow{7}{*}{45.47} \\
\hline & Fish & & 3 & 26.5 & 79.5 & \\
\hline & Potatoes & & 5 & 0.6 & 3 & \\
\hline & Cabbages & & 3 & 1 & 3 & \\
\hline & Bananas & & 1 & 1.2 & 1.2 & \\
\hline & Olive oil & & 2 & 7.6 & 15.2 & \\
\hline & Coffee & & 0.25 & 84.9 & 21.225 & \\
\hline & \multicolumn{4}{|l|}{ Total emissions } & 227.325 & \\
\hline \multirow{8}{*}{3} & Cassava & \multirow{7}{*}{3} & 5 & 2.1 & 10.5 & \multirow{7}{*}{38.38} \\
\hline & Tofu & & 4 & 5.6 & 22.4 & \\
\hline & Egg & & 2 & 8.4 & 16.8 & \\
\hline & Root vegetables & & 4 & 0.6 & 2.4 & \\
\hline & Cane sugar & & 0.5 & 5.1 & 2.55 & \\
\hline & Soybean oil & & 2 & 13.4 & 26.8 & \\
\hline & Dark chocolate & & 0.25 & 134.7 & 33.68 & \\
\hline & \multicolumn{4}{|l|}{ Total emissions } & 115.13 & \\
\hline
\end{tabular}

Source: Authors. 
CALCULATING EMISSIONS OF CLOTHING CONSUMPTION

With more people in emerging economies moving into the middle class, followed by the continued growth of fast fashion, the contribution of such sectors to global emissions is likely to grow. ${ }^{1}$ Global apparel production is estimated to have doubled between 2000 and 2014, and consumers keep most types of apparel only half as long as they did 15 years ago (Remy et al. 2016). Therefore, the increasing popularity of assessing the climate change contribution of the clothing industry is also something to be expected. To further understand this industry, the apparel and footwear value chain are often described in tiers, as shown in Figure 5 .

\section{Figure 5 | Apparel and Footwear Value Chain}

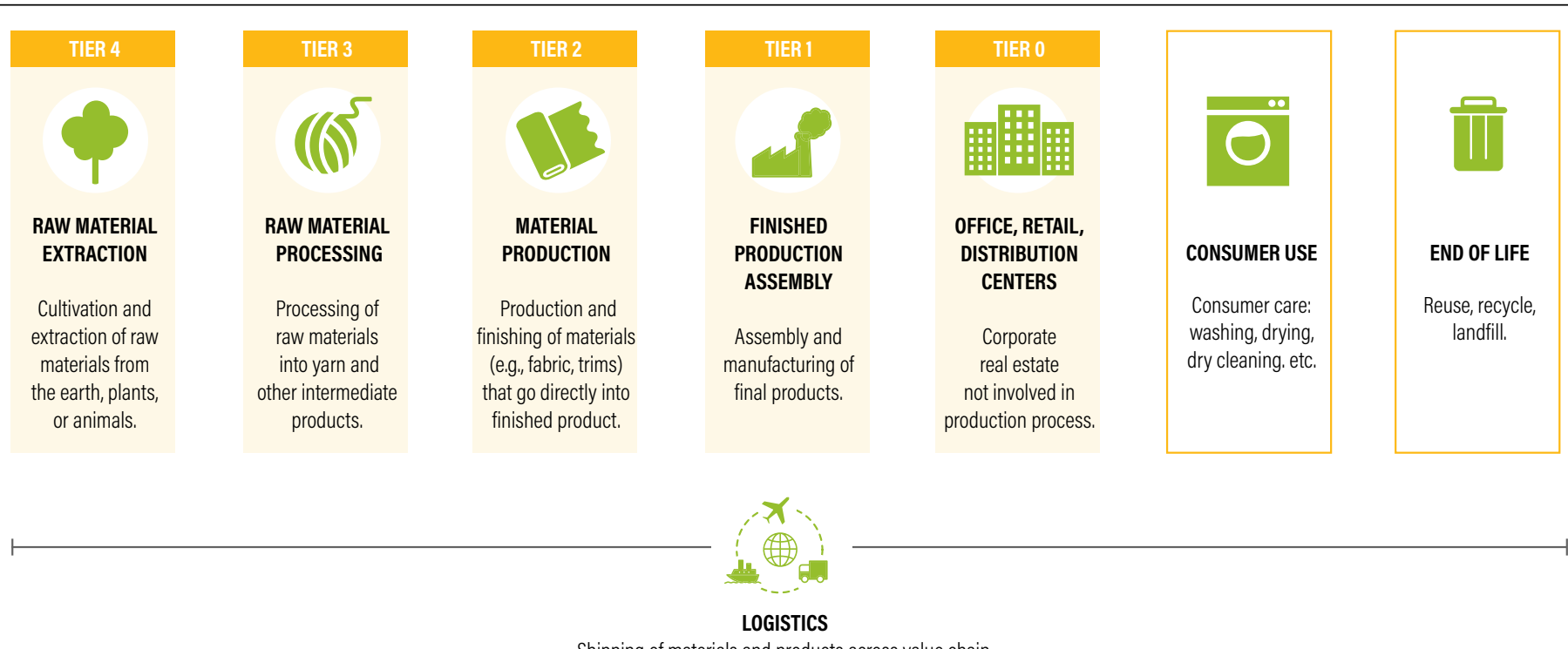

The distribution of GHG emissions across the apparel and footwear value chain is difficult to generalize, due to variation in material type, product design and category, sources, manufacturing country, and other factors that create personalized emissions profiles for different producing companies. However, raw material extraction, dyeing and finishing, yarn preparation, and fiber production (tiers 2 to 4 ) tend to be the most carbon intensive and can account for more than 50 percent of the sector's life-cycle emissions (Quantis 2018). Another important phase in terms of energy use and carbon dioxide emissions is the use phase. It is difficult, however, to determine the way consumers wear and care for different clothing products. Therefore, EMISI limits its focus to calculating emissions from the clothes production phase.

Like food, LCA has recently been used to measure the textile industry's environmental impacts. LCA stages in clothing consist of resource extraction, material production, component production, final clothing production, and management functionality after the product is consumed-either by being re-used, recycled, or discarded (Curran 2017). The all-inclusive system analysis from raw material extraction to the end-of-life product is known as cradle-to-grave. Another common expression in LCA is cradle-to-gate, indicating that raw materials are included but end use and disposal are excluded. This is similar to cradle-to-plate, used in food LCA (Peters et al. 2015).

Based on the LCA approach, calculating emissions from clothing consumption is based on the clothes material, number of clothes, and their emission factors. The LCA refers to the activity-based method suggested by the IPCC (2006). Calculating $\mathrm{CO}_{2}$ from clothing consumption, which uses the activitybased method, requires estimating the number of clothing consumptions per person per year. Clothing consumption is limited to new purchases, not recycled or second-hand products.

The formula for calculating the clothing emission $\mathrm{CO}_{2} \mathrm{e}$ is as follows:

Total clothing emission per person $\left(T C E P_{p}\right)=\sum_{i=1}^{N} \frac{G_{i} x M_{i}}{P_{i}} x E F_{i}$

where $i(i=1,2, \ldots \mathrm{N})$ is the material/textile type $\left(i^{\text {th }}\right)$ of garment (i.e., cotton, polyester, nylon, etc.); $G_{i}$ is the total new purchase (pieces) for the $i^{\text {th }}$ garment; $M_{i}$ is the mass of garment type $(\mathrm{kg})$; and $P_{i}$ is number of persons who used the $\mathrm{i}^{\text {th }}$ garment, which is determined as 1. 
The total clothing consumption per person is the sum of the garment's material, type, and number of purchases, while the $E F_{i}$ is emission factors for $\mathrm{CO}_{2} \mathrm{e}$ based on the garment's material/textile type. The total emission per person is the clothing consumption per person, multiplied by the $E F_{i}$ that is calculated based on cradleto-gate LCA of each garment's material/textile type.

\section{The Determinants of Clothes Emission Factors}

The emission factors for clothes are based on the type of garment and its material/textile component. A study of LCA benchmarking on textiles by van der Velden et al. (2014) attempted to offer insights into the environmental burden of textiles made from the base materials cotton, polyester, nylon, acryl, and elastane. There are two commonly used fibers in the textile industry: natural and man-made. While the former is derived from plant or animal sources such as cotton, wool, flax, and silk, the latter is made from plastic or polymer, such as rayon, nylon, polyester, etc. Cotton is the most widely utilized natural fiber in the world, accounting for over 82 percent of global natural fiber consumption (FAO and ICAC 2015). The calculation itself is presented by four single indicators, including $\mathrm{CO}_{2}$ equivalent (carbon footprint), as shown in Table 3. Van der Velden emission calculations are made for cradle-to-grave; however, for EMISI's purposes, only cradle-to-gate processes of the production chain from raw material extraction to manufactured fabric are included.

Table 3 | Emission Factor of Cotton and Synthetic Textiles

\begin{tabular}{l|l|l|l|l|l|}
\hline \multirow{2}{*}{ Type of material } & \multicolumn{5}{|c|}{ Emission factor (kg CO $\mathbf{2} / \mathbf{k g}$ of materials) } \\
\cline { 2 - 7 } & Cotton & Acryl & Nylon & Polyester & Elastane \\
\hline Fiber & 3.474 & - & - & - & - \\
\hline Polymer pellets & - & 3.04 & 8.638 & 2.698 & 4.836 \\
\hline Pre-treatment & 1.261 & - & - & - & - \\
\hline Weaving 70 dtex & 10.667 & 10.667 & 10.667 & 10.667 & 10.667 \\
\hline Spinning 70 dtex & 7.281 & - & - & - & - \\
\hline Heat setting & & & & & \\
and washing & - & 0.908 & 0.908 & 0.908 & 0.908 \\
synthetic fabrics & & & & & \\
\hline $\begin{array}{l}\text { Texturing polymer } \\
\text { fibers }\end{array}$ & - & 0.505 & 0.505 & 0.505 & 0.505 \\
\hline Extruder spinning & - & 0.896 & 0.896 & 0.896 & 0.896 \\
\hline Total & 22.683 & 16.016 & 21.614 & 15.674 & 17.812 \\
\hline
\end{tabular}

Note: The data comes from European countries and may not accurately represent Indonesia's emission factor.

Source: van der Velden et al. 2014.

\section{The Determinants of Clothes Mass}

Clothes attributes-in this case, clothes mass-is important to model calculations for clothes emission. Clothes mass will be used as a multiplier of emission factor to obtain the total emissions of a garment made by a certain type of fabric or combination of fabrics. As a multiplier, this aspect greatly influences the magnitude of emission. A study of a typical garment's mass is provided in Table 4 (Beton et al. 2009). The determinant of clothing mass is the sum or total mass of new purchase clothing product per person.

Table 4 | Data on Clothing Mass per Garment Type

\begin{tabular}{l|l|}
\hline Garment type & Mass (grams) \\
\hline Tops & 388 \\
\hline Underwear, nightwear, and hosiery & 129 \\
\hline Bottoms & 568 \\
\hline Jackets & 821 \\
\hline Dresses & 1,125 \\
\hline Suits and ensembles & 921 \\
\hline Gloves & 52 \\
\hline Sportswear & 475 \\
\hline Swimwear & 140 \\
\hline Scarves, shawls, ties, etc. & 98 \\
\hline
\end{tabular}

Note: The data comes from Western countries and may not accurately represent garment mass in Indonesia.

Source: Peters et al. 2015.

Calculating emissions for clothing consumption, however, has the following assumptions: (i) due to the complexity of material composition in each garment type, it is assumed that all product is made from 100 percent cotton (mono-material), and (ii) although there are many types and capacities of textile manufacture plants in Indonesia, studies on those plants' emissions are limited; hence, it is assumed that all plants have the same production flow and emission factor, as shown in van der Velden et al. (2014).

An illustration of clothing emission calculations is provided in Table 5. The table presents three scenarios of users with different clothing consumption behaviors. In these cases, the type and amount of garment consumed affect the total emissions. 
Table 5 | Quarterly Clothing Consumption and Emissions Calculation for Three Different EMISI User Scenarios

\begin{tabular}{|c|c|c|c|c|c|}
\hline \multirow{2}{*}{ User scenarios } & Garment type & Clothing consumption (pieces) & Total mass (kg) & $\begin{array}{l}\text { Emission factor } \\
\left(\mathrm{kg} \mathrm{CO} \mathrm{C}_{2} \mathrm{e} / \mathrm{kg}\right)\end{array}$ & Total emission per person $\left(\mathrm{kg} \mathrm{CO}_{2} \mathrm{e}\right)$ \\
\hline & (A) & (B) & (C) & (D) & $(E)=((C) \times(D))$ \\
\hline \multirow{5}{*}{1} & Tops & 2 & 0.776 & 22.683 & 17,60 \\
\hline & Bottoms & 1 & 0.568 & 22.683 & 12.88 \\
\hline & Underwear & 2 & 0.258 & 22.683 & 5.85 \\
\hline & Jackets & 1 & 0.821 & 22.683 & 18.62 \\
\hline & \multicolumn{4}{|c|}{ Total emission per person $(F)=\Sigma(E)$} & 54.96 \\
\hline \multirow{6}{*}{2} & Tops & 3 & 1.164 & 22.683 & 26.40 \\
\hline & Bottoms & 2 & 1.136 & 22.683 & 25.76 \\
\hline & Jackets & 1 & 0.821 & 22.683 & 18.62 \\
\hline & Sportswear & 1 & 0.475 & 22.683 & 10.77 \\
\hline & Nightwear & 2 & 0.258 & 22.683 & 5.85 \\
\hline & \multicolumn{4}{|c|}{ Total emission per person $(F)=\Sigma(E)$} & 87,42 \\
\hline \multirow{4}{*}{3} & Tops & 1 & 0.388 & 22.683 & 8.80 \\
\hline & Underwear & 2 & 0.258 & 22.683 & 5.85 \\
\hline & Bottoms & 1 & 0.568 & 22.683 & 12.88 \\
\hline & \multicolumn{4}{|c|}{ Total emission per person $(F)=\Sigma(E)$} & 27.53 \\
\hline
\end{tabular}

Source: Authors.

The first scenario describes a clothing consumption pattern of middle-class people, whereby the types of garments purchased are those commonly used for daily needs, but are also designed with some elements of style in mind. The second scenario shows the clothing consumption pattern of upper-class people with a higher clothing consumption pattern-a greater number of purchases, more varied types of garments, and high desire for style. The emission from this scenario is highest compared to the other two, because the consumption pattern is mostly driven by desire for style, so the quantity and type of clothing purchases are more than what is needed. The last scenario expresses the clothing consumption pattern that adapts to basic needs of life, whereby functionality drives consumption of clothes. It is shown that emissions from this scenario are lowest compared to the other two, because the quantity and type of clothing purchases are intended to fulfill the basic need to cover and protect the body.

\section{CALCULATING EMISSIONS OF HOUSEHOLD ELECTRICITY CONSUMPTION}

The IPCC's Guidelines for National Greenhouse Gas Inventories (IPCC 2006) classifies residential emission, which includes household appliances as stationary combustion sources of emissions. The guidelines categorize the emission calculation methodology as either top-down or bottom-up. For the EMISI application, the activity-based bottom-up approach is used to calculate the emission of electrical appliances as suggested by the IPCC (2006), considering that users input their appliance usage data. In EMISI, users are asked about their electrical appliances data at any given time. To calculate the total electrical appliances emission, the total electricity used per type of electric appliance based on hours of usage and appliance type are multiplied by the emission factors (Saidur et al. 2007).

The formula to calculate GHG and air pollutant emissions is as follows:

Total electrical emission per person $\left(T E E P_{p}\right)$

$=\sum_{i=1}^{N} \frac{H_{i} x W_{i}}{P_{i}} x \sum_{p=1}^{M} \frac{F_{p}}{\Omega_{p}} x E F s_{p} x \frac{1}{1-\mathrm{TD}_{\mathrm{L}}}$ (3)

where the first part of the formula is to calculate the electricity consumption, where: $i(i=1,2, \ldots N)$ is the number of appliance ( $i^{\text {th }}$ captured; $H_{i}$ is the total duration used per day (hours) for the $i^{i t h}$ appliance; $W_{i}$ is electricity consumption factor for the $i^{\text {th }}$ appliance (watts); and $P_{i}$ is the number of persons that used the $i^{\text {th }}$ appliance. The total electricity used per person is the sum of the electricity consumed calculated throughout all the used appliances. The second part of the formula is to calculate the corrected electricity emission factor, where: $p(\mathrm{p}=1$, $2, \ldots, \mathrm{N}$ ) is the power plant that supplies the electricity grid in Indonesia; $F_{p}$ is fuel mix (\%) factor for $p$ power 
plant; $\Omega$ is power plant net thermal efficiency (\%) based on their fuel type (i.e., coal, gas, oil, hydro, etc.); $E F s_{p}$ is emission factors ( $\mathrm{kg}$ emission or pollutant $/ \mathrm{kWh}$ ) for $\mathrm{CO}_{2}, \mathrm{SO}_{2}$, and $\mathrm{NO}_{\mathrm{x}}$ based on type of the $p$ power plant fuel; and $T D_{L}$ is \% of the transmission and distribution of the electric grid losses. The total emissions per person is the total electricity used per person in the first term, multiplied by the $E F s$ which are corrected based on the Indonesian power plant fuel mix factor and power plant thermal efficiency in the second term of the $T E E P_{p}$ formula.

\section{The Determinants of Electricity Consumption Factors}

To calculate $\mathrm{CO}_{2} \mathrm{SO}_{2}$, and $\mathrm{NO}_{x}$, the activity-based method requires the electricity consumption for every appliance that users input into EMISI. In EMISI, users input their appliances' number of usage hours. The electricity consumption is calculated by multiplying the factors of electricity usage for the type of appliance and the hours of usage. The electricity consumption factor for appliances is based on appliance type (i.e., refrigerator, television, air conditioner, etc.) and is presented in watts. The value of the electricity consumption factor for each appliance type is based on DaftLogic (n.d), Unbound Solar (n.d), and Saidur et al. (2007), which listed the electricity consumption for all appliances. However, to simplify the calculation, only several appliances are used, considering the behavior of electric appliance use in Indonesia (Wijaya and Tezuka 2013). Such electricity consumption factors are provided in Table 6.

Table 6 | Electricity Energy Consumption per Hour, Based on Appliance Type

\begin{tabular}{llll|}
\hline Appliance type & $\mathbf{k W h}^{*}$ & Appliance type & $\mathbf{k W h}^{*}$ \\
\hline $\begin{array}{l}\text { Air conditioner } \\
(\mathrm{AC})^{\mathrm{c}}\end{array}$ & 1.385 & Cell phone $^{\mathrm{b}}$ & 0.007 \\
\hline Fan $^{\mathrm{b}}$ & 0.06 & Personal computer & 0.100 \\
\hline Rice cooker $^{\mathrm{c}}$ & 0.905 & Laptop $^{\mathrm{b}}$ & 0.10 \\
\hline Refrigerator $^{\mathrm{b}}$ & 0.20 & Lighting $^{\mathrm{a}}$ & 0.020 \\
\hline Television $^{\mathrm{c}}$ & 0.08 & Washing machine $^{\mathrm{c}}$ & 1.005 \\
\hline Hair dryer $^{\mathrm{a}}$ & 1.50 & Iron $^{\mathrm{a}}$ & 1.20 \\
\hline
\end{tabular}

Notes: For cell phone, based on cell phone charger; for lighting, refers to a 75 watt LED bulb; * $=$ total energy consumed for one hour of usage.

Sources: a. Unbound Solar n.d.; b. DaftLogic n.d.; c. Saidur et al. 2007.

\section{The Determinants of Electricity Emission Factors}

The EFs for electricity are subject to the type of power plant (PP) that supplies the electricity to the grid. This Technical Note uses EFs from the studies of Damayanti and Khaerunissa (2018), the United States Environmental Protection Agency (US EPA) (2020), and the Energy Information Administration (EIA) (1999). These studies distinguish GHG and air pollutant EFs based on the fuel types used in power plants (i.e., coal, natural gas, and fuel oil), provided in Table 7.

\section{Table 7 | GHG and Air Pollutant Emission Factors for Various Sources of Electricity}

\begin{tabular}{|l|l|l|l|}
\hline $\begin{array}{l}\text { Source of } \\
\text { energy }\end{array}$ & $\begin{array}{l}\mathbf{C O}_{2} \text { emission } \\
\mathbf{( k g / k W h )}\end{array}$ & $\begin{array}{l}\mathbf{N O}_{\mathbf{x}} \text { emission } \\
(\mathbf{k g} / \mathbf{k W h})\end{array}$ & $\begin{array}{l}\mathbf{S O}_{2} \text { emission } \\
(\mathbf{k g} / \mathbf{k W h})\end{array}$ \\
\hline Coal & $0.36689^{\mathrm{a}}$ & $0.000779^{c}$ & $0.004420^{c}$ \\
\hline Natural gas & $0.18104^{\mathrm{b}}$ & $0.000156^{c}$ & $0.0000017^{c}$ \\
\hline Fuel oil & $0.23960^{\mathrm{b}}$ & $0.000764^{c}$ & $0.0019142^{c}$ \\
\hline
\end{tabular}

Sources; a. Damayanti and Khaerunissa 2018; b. EPA 2020; c. EIA 1999.

In Indonesia, $1 \mathrm{kWh}$ of household electricity used is supplied by various PPs (i.e., coal PP, gas PP, oilbased PP, and renewable energy PPs such as hydro PP, geothermal PP, etc.). For converting the complex power mix, EMISI uses Indonesian national-level electricity mix based on the Indonesia Energy Outlook (IEO) 2019 report by the National Energy Council (NEC 2019). The electricity mix is summarized in Table 8.

Table 8 | Indonesia Electricity Mix and Net Thermal Efficiency of Different PPS

\begin{tabular}{l|l|l|l|}
\hline $\begin{array}{l}\text { Power } \\
\text { plant type }\end{array}$ & Fuel & $\begin{array}{l}\text { Electricity } \\
\text { fuel mix } \\
\text { factor (F) }\end{array}$ & $\begin{array}{l}\text { Power plant net } \\
\text { thermal efficiency ( } \mathbf{(})\end{array}$ \\
\hline Coal & Coal & $0.5^{\mathrm{a}}$ & $0.25^{\mathrm{b}}$ \\
\hline Gas & Natural Gas & $0.29^{\mathrm{a}}$ & $0.4^{\mathrm{c}}$ \\
\hline Oil & Diesel & $0.07^{\mathrm{a}}$ & $0.47^{\mathrm{d}}$ \\
\hline Hydro & Hydro & $0.07^{\mathrm{a}}$ & $0.9^{\mathrm{e}}$ \\
\hline Geothermal & Natural heat & $0.0315^{\mathrm{a}}$ & $0.25^{\mathrm{b}}$ \\
\hline Biomass & Biomass & $0.028^{\mathrm{a}}$ & $0.25^{\dagger}$ \\
\hline Other & Solar, wind & $0.0105^{\mathrm{a}}$ & $0.1135^{\mathrm{a}}$ \\
\hline
\end{tabular}

Sources; a. NEC 2019; b. Moran and Shapiro 2010; c. ENGIE n.d.; d. Kanoğlu et al. 2005; e. Singh and Singal 2017; f. Maraver et al. 2013; g. Milosavljević et al. 2015. 
The amount of fuel needed to produce electricity per $\mathrm{kWh}$ is also subject to thermal efficiency correction. Thermal efficiency is the ratio of net heat output for heating, or removal for cooling, to energy input (the coefficient of performance) (Moran and Shapiro 2010). As EMISI considers various PPs in the calculation, the thermal efficiency in EMISI is also divided based on type of PP. The description of thermal efficiency for each PP is described in the far-right column of Table 8. Moreover, the method also considers 9.35 percent of electricity losses during transmission and distribution. This number is based on Indonesia's MoEMR data in 2019 (MoEMR 2020). From the second term in the $T E E P_{p}$ equation, corrected electricity emission factors could be calculated based on the GHG emission and air pollutant emission factors in Table 7 and the electricity fuel mix factor and net thermal efficiency in Table 8. The calculation of corrected electricity emission factors is described in Table 9.

\section{Table 9 | Corrected Electricity Emission Factors}

\begin{tabular}{|l|l|l}
\hline $\begin{array}{l}\text { Type of emission/ } \\
\text { pollutant }\end{array}$ & $\begin{array}{l}\text { Corrected electricity } \\
\text { emission factors }\end{array}$ & Unit \\
\hline $\mathrm{CO}_{2}$ & 0.993622 & $\mathrm{~kg} \mathrm{CO}_{2} / \mathrm{kWh}$ \\
\hline $\mathrm{NO}_{x}$ & 0.001968 & $\mathrm{~kg} \mathrm{NO} / \mathrm{kWh}$ \\
\hline $\mathrm{SO}_{2}$ & 0.010067 & $\mathrm{~kg} \mathrm{SO} / \mathrm{kWh}$ \\
\hline
\end{tabular}

\section{Source: Authors}

This methodology does not take into consideration the context of local electricity mix specific to each electricity grid in Indonesia. This is mainly because the disparity of renewable energy penetration is the result of the local renewable energy source availability. It was found that $1 \mathrm{kWh}$ of electricity usage in Sumatra is less harmful to the environment compared to Java. This is due to higher natural gas and hydropower fuel mix within the Sumatran electricity grid (PLN 2017) compared to the Java-Bali electricity network. It is also believed that environmental impact is the responsibility of each personal user, hence the nationwide electricity mix approach is used to normalize disparity in the renewable fuel mix between electrical grids in Indonesia.
In EMISI, users are asked to input the frequency of their electrical appliance usage in weekly units (number of days per week). To avoid biases, if four weeks are always taken in a month given the variety of number of days (i.e., 31, 30, 28), the calculation of total electricity emission is determined for a three-month period. The three-month period calculation $\left(T E E P_{p}-M\right)$ is conducted by multiplying the $T E E P_{p}$ by total weekly usage frequency and the assumed 13 weeks throughout three months. Hence, the calculation of total electricity emission during a one-year period $\left(T_{\left.E E P_{p}-Y\right)}\right)$ is obtained by multiplying $T E E P_{p}-M$ by four, which represents the total quarters in a year. Examples of these emissions calculations are illustrated below. The calculation examples present two scenarios involving different electricity consumption behaviors that consider different household appliance characteristics that typically appear in Indonesian cities (i.e., metropolitan, medium, and small cities). While metropolitan cities refer to cities that have more than 10 million inhabitants, the medium and small cities have fewer inhabitants with less than 1 million people. The metropolitan cities also tend to have more intensive economy activities, more accessibility to various appliances, higher purchasing power, and more substantial online activity than small cities. Table 10 describes the first scenario, which illustrates a household that uses various electric appliances such as air conditioner, refrigerator, washing machine, laptop, and personal computer. The second scenario (Table 11) illustrates a household that only uses a few appliances (i.e., washing machine, fan, etc.), which represents households in smaller cities. 
Table 10 | Case 1 - Typical Metropolitan City Household Consumption

\begin{tabular}{|c|c|c|c|c|c|c|c|c|c|c|c|}
\hline \multicolumn{12}{|c|}{$\mathrm{CO}_{2}$ emissions } \\
\hline $\begin{array}{l}\text { No. of } \\
\text { appliances }\end{array}$ & $\begin{array}{l}\text { Type of } \\
\text { appliance }\end{array}$ & $\begin{array}{l}\text { Quantity of } \\
\text { appliances }\end{array}$ & $\begin{array}{l}\text { Duration } \\
\text { (h/day) }\end{array}$ & $\begin{array}{l}\text { Wattage } \\
\text { (kWh) }\end{array}$ & Total usage (kWh) & $\begin{array}{l}\text { Corrected } \\
\text { emission } \\
\text { factor (kg } \\
\left.\mathrm{CO}_{2} / \mathrm{kWh}\right)\end{array}$ & $\begin{array}{l}\text { No. of } \\
\text { persons in } \\
\text { household }\end{array}$ & $\begin{array}{l}\text { Total } \mathrm{CO}_{2} \text { emission } \\
\text { per day }\left(\mathrm{kg} \mathrm{CO}_{2}\right)\end{array}$ & $\begin{array}{l}\text { Frequency } \\
\text { of usage } \\
\text { per week }\end{array}$ & $\begin{array}{l}\text { Total } \mathrm{CO}_{2} \\
\text { emission } \\
\text { per week } \\
\text { ( } \mathrm{kg} \mathrm{CO}_{2} \text { ) }\end{array}$ & $\begin{array}{l}\text { Total } \mathrm{CO}_{2} \\
\text { emission per } \\
3 \text { months } \\
\left(\mathrm{kg} \mathrm{CO}_{2}\right)\end{array}$ \\
\hline (A) & (B) & (C) & (D) & (E) & $(F)=(E) *(D) *(C)$ & (G) & (H) & $(\mathrm{l})=((\mathrm{G}) *(\mathrm{~F})) /(\mathrm{H})$ & $(J)$ & $(K)=(I) *(J)$ & $(L)=(K) * 13$ \\
\hline 1 & Fridge & 1 & 24 & 0.2 & 4.8 & 0.994 & 4 & 1.192 & 7 & 8.346 & 108.504 \\
\hline 2 & $\begin{array}{l}\text { Air } \\
\text { conditioner }\end{array}$ & 3 & 12 & 1.385 & 49.86 & 0.994 & 4 & 12.386 & 7 & 86.699 & 1127.081 \\
\hline 3 & $\begin{array}{l}\text { Washing } \\
\text { machine }\end{array}$ & 1 & 3 & 1.005 & 3.015 & 0.994 & 4 & 0.749 & 3 & 2.247 & 29.209 \\
\hline 4 & Laptop & 2 & 8 & 0.1 & 1.6 & 0.994 & 4 & 0.397 & 5 & 1.987 & 25.834 \\
\hline 5 & Cell phone & 4 & 18 & 0.007 & 0.504 & 0.994 & 5 & 0.100 & 6 & 0.601 & 7.812 \\
\hline 6 & Lamp & 6 & 12 & 0.02 & 1.44 & 0.994 & 4 & 0.358 & 7 & 2.504 & 32.551 \\
\hline \multicolumn{12}{|c|}{$\mathrm{SO}_{2}$ emissions } \\
\hline $\begin{array}{l}\text { No. of } \\
\text { appliances }\end{array}$ & \begin{tabular}{|l|}
$\begin{array}{l}\text { Type of } \\
\text { appliance }\end{array}$ \\
\end{tabular} & $\begin{array}{l}\text { Quantity of } \\
\text { appliances }\end{array}$ & \begin{tabular}{|l|} 
Duration \\
(h/day)
\end{tabular} & $\begin{array}{l}\text { Wattage } \\
\text { (kWh) }\end{array}$ & Total usage (kWh) & \begin{tabular}{|l|} 
Corrected \\
emission \\
factor (kg \\
$\left.\mathrm{SO}_{2} / \mathrm{kWh}\right)$
\end{tabular} & $\begin{array}{l}\text { No. of } \\
\text { persons in } \\
\text { household }\end{array}$ & $\begin{array}{l}\text { Total } \mathrm{SO}_{2} \text { emission } \\
\text { per day }\left(\mathrm{kg} \mathrm{SO}_{2}\right)\end{array}$ & $\begin{array}{l}\text { Frequency } \\
\text { of usage } \\
\text { per week }\end{array}$ & $\begin{array}{l}\text { Total } \mathrm{SO}_{2} \\
\text { emission } \\
\text { per week } \\
\text { (kg SO})\end{array}$ & $\begin{array}{l}{\mathrm{Total} \mathrm{SO}_{2}} \text { emission per } \\
3 \text { months } \\
\left(\mathrm{kg} \mathrm{SO}_{2}\right)\end{array}$ \\
\hline (A) & (B) & (C) & (D) & (E) & $(F)=(E) *(D) *(C)$ & (G) & (H) & $(\mathrm{l})=((\mathrm{G}) *(\mathrm{~F})) /(\mathrm{H})$ & $(J)$ & $(\mathrm{K})=(\mathrm{I}) *(\mathrm{~J})$ & $(L)=(K) * 13$ \\
\hline 1 & Fridge & 1 & 24 & 0.2 & 4.8 & 0.010 & 4 & 0.012 & 7 & 0.085 & 1.099 \\
\hline 2 & $\begin{array}{l}\text { Air } \\
\text { conditioner }\end{array}$ & 3 & 12 & 1.385 & 49.86 & 0.010 & 4 & 0.125 & 7 & 0.878 & 11.420 \\
\hline 3 & $\begin{array}{l}\text { Washing } \\
\text { machine }\end{array}$ & 1 & 3 & 1.005 & 3.015 & 0.010 & 4 & 0.008 & 3 & 0.023 & 0.296 \\
\hline 4 & Laptop & 2 & 8 & 0.1 & 1.6 & 0.010 & 4 & 0.004 & 5 & 0.020 & 0.262 \\
\hline 5 & Cell phone & 4 & 18 & 0.007 & 0.504 & 0.010 & 5 & 0.001 & 6 & 0.006 & 0.079 \\
\hline 6 & Lamp & 6 & 12 & 0.02 & 1.44 & 0.010 & 4 & 0.004 & 7 & 0.025 & 0.330 \\
\hline \multicolumn{12}{|c|}{ NOx emissions } \\
\hline $\begin{array}{l}\text { No. of } \\
\text { appliances }\end{array}$ & \begin{tabular}{|l|} 
Type of \\
appliance
\end{tabular} & $\begin{array}{l}\text { Quantity of } \\
\text { appliances }\end{array}$ & $\begin{array}{l}\text { Duration } \\
\text { (h/day) }\end{array}$ & $\begin{array}{l}\text { Wattage } \\
\text { (kWh) }\end{array}$ & Total usage (kWh) & $\begin{array}{l}\text { Corrected } \\
\text { emission } \\
\text { factor (kg } \\
\text { NOx/kWh) }\end{array}$ & $\begin{array}{l}\text { No. of } \\
\text { persons in } \\
\text { household }\end{array}$ & $\begin{array}{l}\text { Total NOx } \\
\text { emission per day } \\
\text { ( } k g \text { NOx) }\end{array}$ & \begin{tabular}{|l|} 
Frequency \\
of usage \\
per week
\end{tabular} & $\begin{array}{l}\text { Total NOx } \\
\text { emission } \\
\text { per week } \\
\text { (kg NOx) }\end{array}$ & $\begin{array}{l}\text { Total NOx } \\
\text { emission per } \\
3 \text { months } \\
\text { (kg NOx) }\end{array}$ \\
\hline (A) & (B) & (C) & (D) & (E) & $(F)=(E) *(D) *(C)$ & (G) & (H) & $(\mathrm{I})=((\mathrm{G}) *(\mathrm{~F})) /(\mathrm{H})$ & $(J)$ & $(K)=(I) *(J)$ & $(L)=(K) * 13$ \\
\hline 1 & Fridge & 1 & 24 & 0.2 & 4.8 & 0.002 & 4 & 0.002 & 7 & 0.017 & 0.215 \\
\hline 2 & $\begin{array}{l}\text { Air } \\
\text { conditioner }\end{array}$ & 3 & 12 & 1.385 & 49.86 & 0.002 & 4 & 0.025 & 7 & 0.172 & 2.233 \\
\hline 3 & $\begin{array}{l}\text { Washing } \\
\text { machine }\end{array}$ & 1 & 3 & 1.005 & 3.015 & 0.002 & 4 & 0.001 & 3 & 0.004 & 0.058 \\
\hline 4 & Laptop & 2 & 8 & 0.1 & 1.6 & 0.002 & 4 & 0.001 & 5 & 0.004 & 0.051 \\
\hline 5 & Cell phone & 2 & 24 & 0.007 & 0.336 & 0.002 & 5 & 0.000 & 6 & 0.001 & 0.010 \\
\hline 6 & Lamp & 1 & 24 & 0.02 & 0.48 & 0.002 & 4 & 0.000 & 7 & 0.002 & 0.022 \\
\hline
\end{tabular}

Source: Authors. 
Table 11 | Case 2 - Typical Small City Household Consumption

\begin{tabular}{|c|c|c|c|c|c|c|c|c|c|c|c|}
\hline \multicolumn{12}{|c|}{$\mathrm{CO}_{2}$ emissions } \\
\hline $\begin{array}{l}\text { No. of } \\
\text { appliances }\end{array}$ & $\begin{array}{l}\text { Type of } \\
\text { appliance }\end{array}$ & $\begin{array}{l}\text { Quantity of } \\
\text { appliances }\end{array}$ & $\begin{array}{l}\text { Duration } \\
\text { (h/day) }\end{array}$ & $\begin{array}{l}\text { Wattage } \\
\text { (kWh) }\end{array}$ & Total usage (kWh) & $\begin{array}{l}\text { Corrected } \\
\text { emission } \\
\text { factor (kg } \\
\mathrm{CO}_{2} / \mathrm{kWh} \text { ) }\end{array}$ & \begin{tabular}{|l} 
No. of \\
persons in \\
household
\end{tabular} & $\begin{array}{l}\text { Total } \mathrm{CO}_{2} \text { emission } \\
\text { per day }\left(\mathrm{kg} \mathrm{CO}_{2}\right)\end{array}$ & $\begin{array}{l}\text { Frequency } \\
\text { of usage } \\
\text { per week }\end{array}$ & $\begin{array}{l}\text { Total } \mathrm{CO}_{2} \\
\text { emission } \\
\text { per week } \\
\left(\mathrm{kg} \mathrm{CO}_{2}\right)\end{array}$ & $\begin{array}{l}\text { Total } \mathrm{CO}_{2} \\
\text { emission per } \\
3 \text { months } \\
\left(\mathrm{kg} \mathrm{CO}_{2}\right)\end{array}$ \\
\hline (A) & (B) & (C) & (D) & $\overline{(E)}$ & $(F)=(E) *(D) *(C)$ & $\overline{(G)}$ & (H) & $(\mathrm{I})=((\mathrm{G}) *(\mathrm{~F})) /(\mathrm{H})$ & (J) & $(\mathrm{K})=(\mathrm{I}) *(\mathrm{~J})$ & $(\mathrm{L})=(\mathrm{K}) * 13$ \\
\hline 1 & Fan & 1 & 12 & 0.06 & 0.72 & 0.994 & 4 & 0.179 & 7 & 1.252 & 16.276 \\
\hline 2 & $\begin{array}{l}\text { Washing } \\
\text { Machine }\end{array}$ & 1 & 3 & 1.005 & 3.015 & 0.994 & 4 & 0.749 & 3 & 2.247 & 29.209 \\
\hline 3 & Television & 1 & 24 & 0.08 & 1.92 & 0.994 & 4 & 0.477 & 7 & 3.339 & 43.401 \\
\hline 4 & Cell-phone & 2 & 16 & 0.007 & 0.224 & 0.994 & 5 & 0.045 & 8 & 0.356 & 4.629 \\
\hline 5 & Lamp & 5 & 12 & 0.02 & 1.2 & 0.994 & 4 & 0.298 & 7 & 2.087 & 27.126 \\
\hline
\end{tabular}

\begin{tabular}{|c|c|c|c|c|c|c|c|c|c|c|c|}
\hline \multicolumn{12}{|c|}{$\mathrm{SO}_{2}$ emissions } \\
\hline $\begin{array}{l}\text { No. of } \\
\text { appliances }\end{array}$ & $\begin{array}{l}\text { Type of } \\
\text { appliance }\end{array}$ & $\begin{array}{l}\text { Quantity of } \\
\text { appliances }\end{array}$ & $\begin{array}{l}\text { Duration } \\
\text { (h/day) }\end{array}$ & $\begin{array}{l}\text { Wattage } \\
\text { (kWh) }\end{array}$ & Total usage (kWh) & $\begin{array}{l}\text { Corrected } \\
\text { emission } \\
\text { factor (kg } \\
\mathrm{SO}_{2} / \mathrm{kWh} \text { ) }\end{array}$ & $\begin{array}{l}\text { No. of } \\
\text { persons in } \\
\text { household }\end{array}$ & $\begin{array}{l}\text { Total SO2 emission } \\
\text { per day } \\
\left(\mathrm{kg} \mathrm{SO}_{2}\right)\end{array}$ & $\begin{array}{l}\text { Frequency } \\
\text { of usage } \\
\text { per week }\end{array}$ & $\begin{array}{l}\mathrm{Total} \mathrm{SO}_{2} \\
\text { emission } \\
\text { per week } \\
\left(\mathrm{kg} \mathrm{SO}_{2}\right)\end{array}$ & $\begin{array}{l}\text { Total } \mathrm{SO}_{2} \\
\text { emission per } \\
3 \text { months } \\
\left(\mathrm{kg} \mathrm{SO}_{2}\right)\end{array}$ \\
\hline (A) & (B) & (C) & (D) & (E) & $(F)=(E) *(D) *(C)$ & (G) & (H) & $(\mathrm{I})=((\mathrm{G}) *(\mathrm{~F})) /(\mathrm{H})$ & (J) & $(K)=(I) *(J)$ & $(L)=(K) * 13$ \\
\hline 1 & Fan & 2 & 12 & 0.06 & 1.44 & 0.010 & 4 & 0.004 & 7 & 0.025 & 0.330 \\
\hline 2 & $\begin{array}{l}\text { Washing } \\
\text { machine }\end{array}$ & 1 & 3 & 1.005 & 3.015 & 0.010 & 4 & 0.008 & 3 & 0.023 & 0.296 \\
\hline 3 & Television & 1 & 8 & 0.08 & 0.64 & 0.010 & 4 & 0.002 & 7 & 0.011 & 0.147 \\
\hline 4 & Cell phone & 2 & 16 & 0.007 & 0.224 & 0.010 & 5 & 0.000 & 8 & 0.004 & 0.047 \\
\hline 5 & Lamp & 5 & 12 & 0.02 & 1.2 & 0.010 & 4 & 0.003 & 7 & 0.021 & 0.275 \\
\hline
\end{tabular}

\begin{tabular}{|c|c|c|c|c|c|c|c|c|c|c|c|}
\hline \multicolumn{12}{|c|}{ NOx emissions } \\
\hline $\begin{array}{l}\text { No. of } \\
\text { appliances }\end{array}$ & $\begin{array}{l}\text { Type of } \\
\text { appliance }\end{array}$ & $\begin{array}{l}\text { Quantity of } \\
\text { appliances }\end{array}$ & $\begin{array}{l}\text { Duration } \\
\text { (h/day) }\end{array}$ & $\begin{array}{l}\text { Wattage } \\
\text { (kWh) }\end{array}$ & Total usage (kWh) & $\begin{array}{l}\text { Corrected } \\
\text { emission } \\
\text { factor (kg } \\
\text { NOx/kWh) }\end{array}$ & $\begin{array}{l}\text { No. of } \\
\text { persons in } \\
\text { household }\end{array}$ & $\begin{array}{l}\text { Total NOx emission } \\
\text { per day } \\
\text { (kg NOx) }\end{array}$ & $\begin{array}{l}\text { Frequency } \\
\text { of usage } \\
\text { per week }\end{array}$ & $\begin{array}{l}\text { Total NOx } \\
\text { emission } \\
\text { per week } \\
\text { (kg NOx) }\end{array}$ & $\begin{array}{l}\text { Total NOx } \\
\text { emission per } \\
3 \text { months } \\
\text { (kg NOx) }\end{array}$ \\
\hline (A) & (B) & (C) & (D) & (E) & $(F)=(E) *(D) *(C)$ & (G) & (H) & $(\mathrm{I})=((\mathrm{G}) *(\mathrm{~F})) /(\mathrm{H})$ & (J) & $(K)=(I) *(J)$ & $(\mathrm{L})=(\mathrm{K}) * 13$ \\
\hline 1 & Fan & 2 & 12 & 0.06 & 1.44 & 0.002 & 4 & 0.001 & 7 & 0.005 & 0.065 \\
\hline 2 & $\begin{array}{l}\text { Washing } \\
\text { machine }\end{array}$ & 1 & 3 & 1.005 & 3.015 & 0.002 & 4 & 0.001 & 3 & 0.004 & 0.058 \\
\hline 3 & Television & 1 & 8 & 0.08 & 0.64 & 0.002 & 4 & 0.000 & 7 & 0.002 & 0.029 \\
\hline 4 & Cell phone & 2 & 16 & 0.007 & 0.224 & 0.002 & 5 & 0.000 & 8 & 0.001 & 0.009 \\
\hline 5 & Lamp & 5 & 12 & 0.02 & 1.2 & 0.002 & 4 & 0.001 & 7 & 0.004 & 0.054 \\
\hline
\end{tabular}

Source: Authors. 


\section{CALCULATING EMISSIONS OF HOUSEHOLD SOLID WASTE}

IPCC (2006) generally defines municipal solid waste (MSW) as waste collected by municipalities or other local authorities. These MSW residuals are generally classified as household waste; garden (yard/park) waste; and commercial/institutional waste (IPCC 2006). For individual lifestyle emission sources in EMISI, the MSW calculation is subject to the waste generated by individuals in a household as well as their necessary yard waste. Any specific, hazardous, or wastewater residuals are not covered in the calculations described in the following section.

EMISI measures emissions from household residuals based on emissions created from treatment processes as well as the subsequent emissions from corresponding activities (i.e., transportation, use of machinery, etc.). This calculation requires a two-step activity data input by users. The first step involves information on waste mass and its composition by a certain household. On the one hand, the mass of waste directly influences larger emissions for the management process, as well as its required transport. On the other hand, the composition determines the specific management process the waste would potentially experience in the Indonesian context.

The second step is measuring the emissions generated from the management process that the waste will potentially experience. These different waste management processes will vary based on an individual's location, in which they are required to input their city type (rural/ urban) as the closest proxy chosen. For example, rural areas tend to process their waste through open burning and composting, while urban areas tend to rely more on landfills and random dumping based on current available data in Indonesia. Finally, the total emissions from waste a household would have is expressed through the following equation, adopted from Kristanto and Koven (2019) on estimating waste emissions in Depok City, Indonesia:

Total waste emission per person (TWEP $)$

$=\sum_{i=1}^{n}\left(E F s_{i} \cdot m_{i}\right)+\sum_{i=1}^{\mathrm{n}}\left(E F s_{t} \cdot \frac{m_{i}}{c a p} \cdot d\right)(4)$

where the first part of the formula is to calculate the mass of disposed waste, $m_{i}(\mathrm{~kg})$ is the content of different mass of disposed waste, and $E F s_{i}\left(\mathrm{CO}_{2}, \mathrm{CH}_{4}\right.$, and $\left.\mathrm{N}_{2} \mathrm{O}\right)$ is the emission factor for different waste management types (i.e., open burning, uncontrolled landfill, etc.). The second part illustrates emissions from transportation, where $E F s_{t}$ is the emission factor for transportation, cap is the maximum capacity $(\mathrm{kg})$ of waste transportation vehicles used in Indonesia, and $d$ is the average distance $(\mathrm{km})$ between waste disposal sites and households.

\section{The Determinants of Household Solid Waste Disposal Streams}

MSW residuals contribute to climate change primarily through GHG emissions of carbon dioxide $\left(\mathrm{CO}_{2}\right)$, methane $\left(\mathrm{CH}_{4}\right)$ and nitrous oxide $\left(\mathrm{N}_{2} \mathrm{O}\right)$ in an attempt to dispose these residuals (IFEU 2009). As different disposal treatments generate different amounts and types of greenhouse gas pollutants, identifying which waste management systems are relevant to the specific individual is a subject that needs to be addressed. Therefore, the IPCC approach to calculating GHG emissions from waste has used a bottom-up, activity-based approach, starting from identifying prior information on waste generation, composition, and determining which treatment would be required to dispose of the household's residual waste (IPCC 2006). The waste streams in Indonesia for organic and inorganic waste based on most updated data (taken in 2009) are illustrated in Table 12.

Table 12 | Urban-Rural Portion of Waste Streams and Management System in Indonesia

\begin{tabular}{|c|c|c|c|c|}
\hline \multirow{2}{*}{ Management system } & \multicolumn{2}{|l|}{ Rural } & \multicolumn{2}{|l|}{ Urban } \\
\hline & (\%) Organics & (\%) Inorganics & (\%) Organics & (\%) Inorganics \\
\hline Open burning & $33.37 \%$ & $57.86 \%$ & $5.86 \%$ & $5.62 \%$ \\
\hline Uncontrolled landfill & $4.45 \%$ & $7.71 \%$ & $47.93 \%$ & $45.98 \%$ \\
\hline Composting & $45.50 \%$ & $\mathrm{n} / \mathrm{a}$ & $2 \%$ & $\mathrm{n} / \mathrm{a}$ \\
\hline Recycled inorganics (3R) & $\mathrm{n} / \mathrm{a}$ & $5.50 \%$ & $\mathrm{n} / \mathrm{a}$ & $6 \%$ \\
\hline Random dumping and discharge & $16.68 \%$ & $28.93 \%$ & $44.21 \%$ & $42.40 \%$ \\
\hline
\end{tabular}

Source: Normalized data from Ministry of National Development Planning 2010. 
As previously stated, waste streams in Indonesia are remarkably diverse between regions, but with such limited information, EMISI acknowledges the geographical differences of waste management systems through categorization of urban and rural practices as the chosen proxy. This differentiation would affect the value of emissions released by individuals based on these two categories. For example, local authorities and communities in rural areas tend to conduct more open burning, while urban areas rely more on landfilling and random dumping disposals. This would result in higher potential emissions released by individuals in rural areas.

\section{The Determinants of Waste Management System Emission Factors}

Calculating emission factors is possible after the individual's potential waste management process has been identified. The EFs for waste disposal are subject to the type of waste management process, as illustrated by Table 13.

Table 13 | Emission Factors for Various Waste Management Systems and Their Transportation

\begin{tabular}{|c|c|c|c|}
\hline Transport & Emission type & Unit & Emission factor \\
\hline \multirow{2}{*}{ Transportation ${ }^{\mathrm{a}}$} & $\mathrm{CO}_{2}$ & $\mathrm{~kg} \mathrm{CO} / \mathrm{km} / \mathrm{kg} \mathrm{MSW}$ & 0.0000191 \\
\hline & $\mathrm{N}_{2} \mathrm{O}$ & $\mathrm{kg} \mathrm{CO} \mathrm{CO}_{2} / \mathrm{km} / \mathrm{kg} \mathrm{MSW}$ & 0.0000497 \\
\hline Waste management type & Emission type & Unit & Emission factor \\
\hline \multirow{2}{*}{ Composting $^{\mathrm{a}}$} & $\mathrm{CH}_{4}$ & $\mathrm{~kg} \mathrm{CO} 2 \mathrm{e} / \mathrm{kg} \mathrm{MSW}$ & 0.1000000 \\
\hline & $\mathrm{N}_{2} \mathrm{O}$ & $\mathrm{kg} \mathrm{CO} 2 \mathrm{e} / \mathrm{kg} \mathrm{MSW}$ & 0.0029944 \\
\hline \multirow{3}{*}{ Open burning ${ }^{\mathrm{a}}$} & $\mathrm{CO}_{2}$ & $\mathrm{~kg} \mathrm{CO} / \mathrm{kg} \mathrm{MSW}$ & 0.0333764 \\
\hline & $\mathrm{CH}_{4}$ & $\mathrm{~kg} \mathrm{CO} 2 \mathrm{e} / \mathrm{kg} \mathrm{MSW}$ & 0.0067535 \\
\hline & $\mathrm{N}_{2} \mathrm{O}$ & $\mathrm{kg} \mathrm{CO} 2 \mathrm{e} / \mathrm{kg} \mathrm{MSW}$ & 0.0018382 \\
\hline Random dumping and discharge ${ }^{b}$ & $\mathrm{CO}_{2}$ & $\mathrm{~kg} \mathrm{CO}_{2} / \mathrm{kg} \mathrm{MSW}$ & 0.7500000 \\
\hline \multirow{2}{*}{ Recycled inorganics (3R) ${ }^{b}$} & $\mathrm{CO}_{2}$ & $\mathrm{~kg} \mathrm{CO}_{2} / \mathrm{kg} \mathrm{MSW}$ & -0.0022370 \\
\hline & $\mathrm{N}_{2} \mathrm{O}$ & $\mathrm{kg} \mathrm{CO} 2 \mathrm{e} / \mathrm{kg} \mathrm{MSW}$ & -0.0000001 \\
\hline \multirow{2}{*}{ Uncontrolled landfilla } & $\mathrm{CO}_{2}$ & $\mathrm{~kg} \mathrm{CO} / \mathrm{kg} \mathrm{MSW}$ & 0.2100000 \\
\hline & $\mathrm{CH}_{4}$ & $\mathrm{~kg} \mathrm{CO} 2 \mathrm{e} / \mathrm{kg} \mathrm{MSW}$ & 0.0750000 \\
\hline
\end{tabular}

Note: Recycling inorganics makes disposing of the waste unnecessary, thereby avoiding emissions. Therefore, the values of recycled inorganics in the 2009 Ministry of National Development Planning study have been determined as negative.

Sources: a. Kristanto and Koven 2019; b. Ministry of National Development Planning 2010.

While national- or district-level data regarding waste disposal is commonly available, it is uncertain whether a specific individual's residuals will be part of a certain waste system process. For example, if national-level data show that 5 percent of inorganics are being recycled, there is no certainty that a particular individual's inorganic trash is included in this 5 percent. The uncertainty originates from the inability to control what kind of waste management system would be implemented to such individual's waste. In consideration of this fact, the calculation uses a statistical approach to quantify the probability of individuals' chances of alignment with certain waste management systems through uncertainty analysis. The uncertainty analysis that is based on waste system data from Indonesia (2005) is described in Appendix A.

The calculation implements a \pm 20 percent range from the default values and Latin Hypercube Sampling (LHS) (McKay 1992) is chosen to sample the data within the designated range. For each location and waste type, 1,00o cases are previously self-simulated and statistically analyzed. The cumulative distribution function (CDF) results for each case can be seen in Appendix A. With a chosen CDF value of 90 percent in consideration of data quality available, the GHG emissions on a kilogram-based value between different data input categories are summarized in Table 14. 


\begin{tabular}{|c|c|c|c|}
\hline \multirow{2}{*}{ City category and waste content } & \multicolumn{3}{|c|}{ GHG emissions and pollutants } \\
\hline & $\mathrm{kg} \mathrm{CH}_{4} / \mathrm{kg}$ of waste & $\mathrm{kg} \mathrm{CO} / \mathrm{kg}$ of waste & $\mathrm{kg} \mathrm{N}_{2} \mathrm{O} / \mathrm{kg}$ of waste \\
\hline \multicolumn{4}{|l|}{ Rural cities } \\
\hline Organic content & 0.111 & 0.45 & 0.501 \\
\hline Inorganic content & 0.105 & 0.668 & 0.0275 \\
\hline \multicolumn{4}{|l|}{ Urban cities } \\
\hline Organic content & 0.055 & 0.052 & 0.045 \\
\hline Inorganic content & 0.04 & 0.45 & 0.0004 \\
\hline
\end{tabular}

Source: Authors.

Direct examples of the calculation method in practice are illustrated in Table 15. The appendix provides different cases of waste weight, composition, as well as other influential factors that create the correlated GHG emissions and air pollutants. The examples show key correlations, such as inorganic mass, which has more pollutants compared to organic ones. Additionally, in general, higher results are shown from rural locations due to their management practices that still often consist of open burning, while residents in urban areas rely more on landfilling.

Since data on waste is often limited in nature (Damanhuri et al. 2014), the calculation of GHG emissions from waste in the context of Indonesia would seem to have some limitations. The identified limitations include:

Waste composition. The common user may not possess information on the precise composition of their waste. In light of this challenge, waste composition input is simplified into organics (food scraps and yard waste) and inorganics (cardboards, plastic, diapers, metal, etc.) for user convenience. However, the different GHG result calculations from different waste compositions are still accounted for in the emission factors of the waste system itself.
Waste management process in distinct locations. The EMISI calculation still acknowledges different geographical practices through the categorization of urban-rural practices as the chosen proxy. While such categorization may be quite conventional considering various waste practices used between different areas, the different practices and results between these two categories could still be shown.

- Vehicle capacity and travel distance. It is a challenge to accurately estimate the range and vehicle capacity used between waste systems in varieties of locations for different individuals. Our calculation estimates both travel distance and vehicle capacity based on field surveys across Indonesia (Ministry of National Development Planning 2010), with a distance (d) of 25 kilometers on average and vehicle capacity (cap) of 2,500 kilograms of wet waste. 


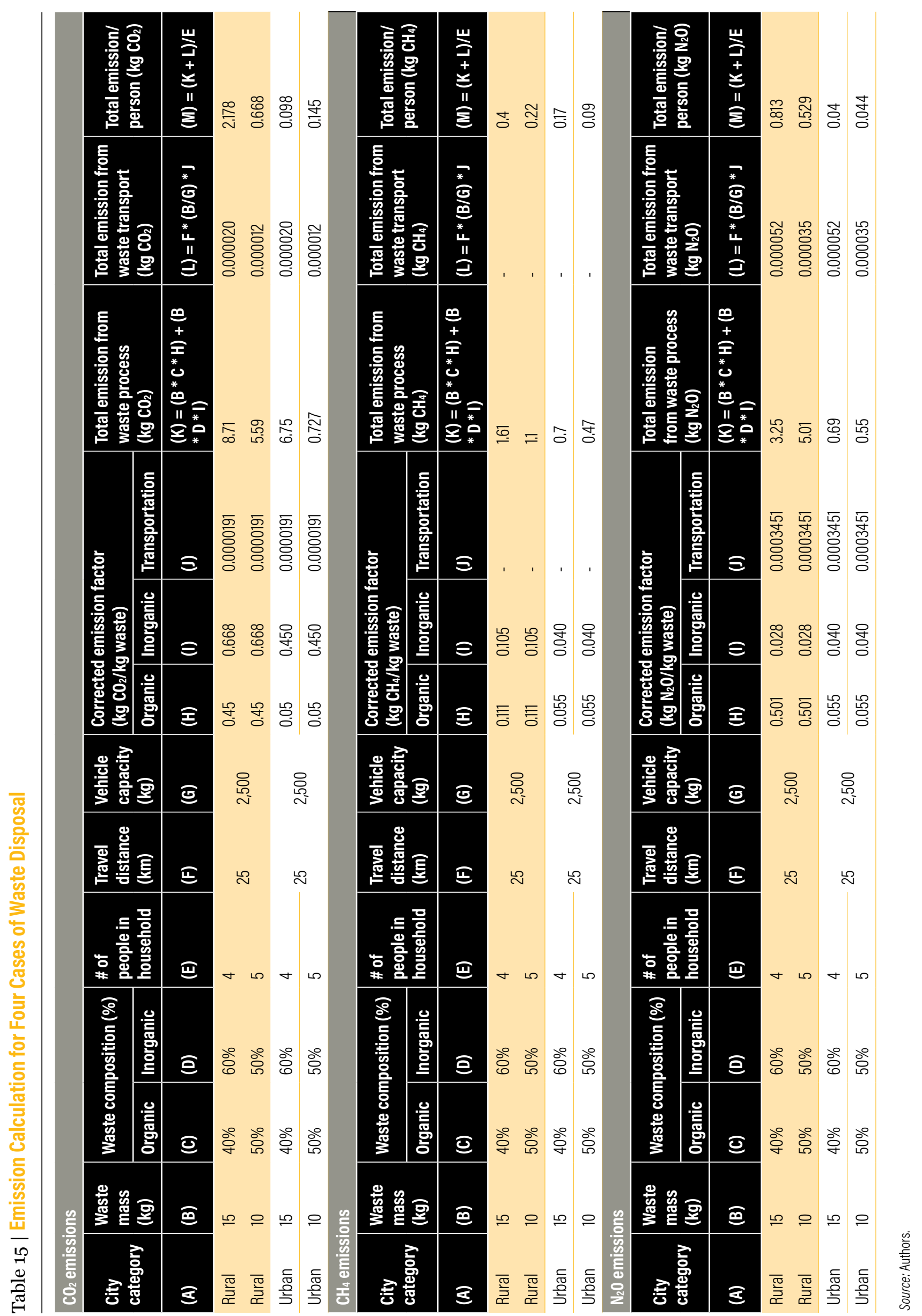


EMISI utilizes the most appropriate method and best available data for emission calculation in the Indonesian context. Most of the calculations of household emissions are subject to local aspects such as emission factors, due to dependency on existing conditions (i.e., availability of technology, materials, etc.). Therefore, compared with other calculators, this Technical Note shows relatively consistent calculation, especially compared to countries with similar characteristics. For instance, in electricity emission calculations, this Technical Note shows insignificant differences from Australianrelated calculators (Carbon Neutral n.d.). This is given the fact that coal accounts for about 75 percent of Australia's electricity generation (Geoscience Australia n.d.), similar to Indonesia's. However, compared with European-related calculators (National Energy Foundation 2017), the differences are significant due to the characteristics of European power plants. Such facts indicate that local factors are important to make this methodology suitable for Indonesian society. However, given Indonesia's conditions, the methodology in this Technical Note is subject to more limitations, as explained in the following.

While the formulas for the emission calculations are quite simple, as demonstrated by the IPCC (2006), in developing countries such as Indonesia, data availability has been a barrier. For both food and clothing sectors, emission factors used to calculate emissions in EMISI are derived by compiling relevant LCA studies. Yet comprehensive studies that estimate the climate impact of Indonesian food and clothing are still limited. Hence, emission estimations from food and clothing in EMISI may not always accurately reflect the entire process of food and clothing production in Indonesia, despite given the best estimates through optimized utilization of available data.

Furthermore, the household emission calculation relies on the accuracy of EFs, which are subject to various variables. For the electricity consumption sector, the emission factor depends on the quality of the fuel (i.e., coal, fuel, gas) of PP and PP technology that differ based on spatial locations. Moreover, the methodology uses average value for appliance electricity consumption, while in reality it is influenced also by age of the appliance, which affects efficiency of electricity usage.
While the waste management system and composition of waste are fundamental factors for calculating waste emissions, the type of garment or food is important for calculating clothing and food emissions. With the improvement of technology and subsequent improvements of the EFs, this Technical Note also highly encourages further localization and updated data for such determinants in the future. Therefore, EMISI will continuously revise its technical assumptions (i.e., emission factors, energy efficiency factors, etc.) when updated data are available.

Moreover, emission factors for the food sector are calculated as $\mathrm{kg} \mathrm{CO}_{2} \mathrm{e}$ by combining all GHG emissions, including $\mathrm{CO}_{2}, \mathrm{CH}_{4}$, and $\mathrm{N}_{2} \mathrm{O}$, into $\mathrm{CO}_{2}$ equivalent, since most LCA studies provide the results in $\mathrm{CO}_{2} \mathrm{e}$. Also, other emission factors for air pollutants in the clothing sector, such as $\mathrm{SO}_{2}, \mathrm{NO}_{x}, \mathrm{CO}, \mathrm{PM}$, etc., contained in $\mathrm{CO}_{2} \mathrm{e}$ are generally sourced from chemicals used in the fabric manufacturing process, and varies widely depending on the type of textile factory, the size or production capacity of the factory, the type of fabric produced, and the type of required treatment. Therefore, emissions of other pollutants per $\mathrm{kg}$ of fabric production are not reflected in clear details, and are hence excluded from EMISI's calculation.

Besides emission factors used in the calculation method, another limitation of this Technical Note pertains to the fact that emissions will only be calculated based on data provided by users. Therefore, there is no guarantee regarding the accuracy of household activity data provided, as users may over-or underreport their consumption and waste. However, this does not diminish EMISI's overall goal of educating the public about the environmental impact of their lifestyle. 


\section{APPENDIX A: CUMULATIVE DISTRIBUTION FUNCTIONS FROM WASTE STREAM UNCERTAINTY ANALYSIS}

Figure A1 | Uncertainty Analysis CDF Plots for Rural Organic and Inorganic Waste (kg) Based on Waste Stream Data from Indonesia (2005)

CDF Plots for Rural Inorganic Waste

$\mathrm{CDF}$ for $\mathrm{CH}_{4}$

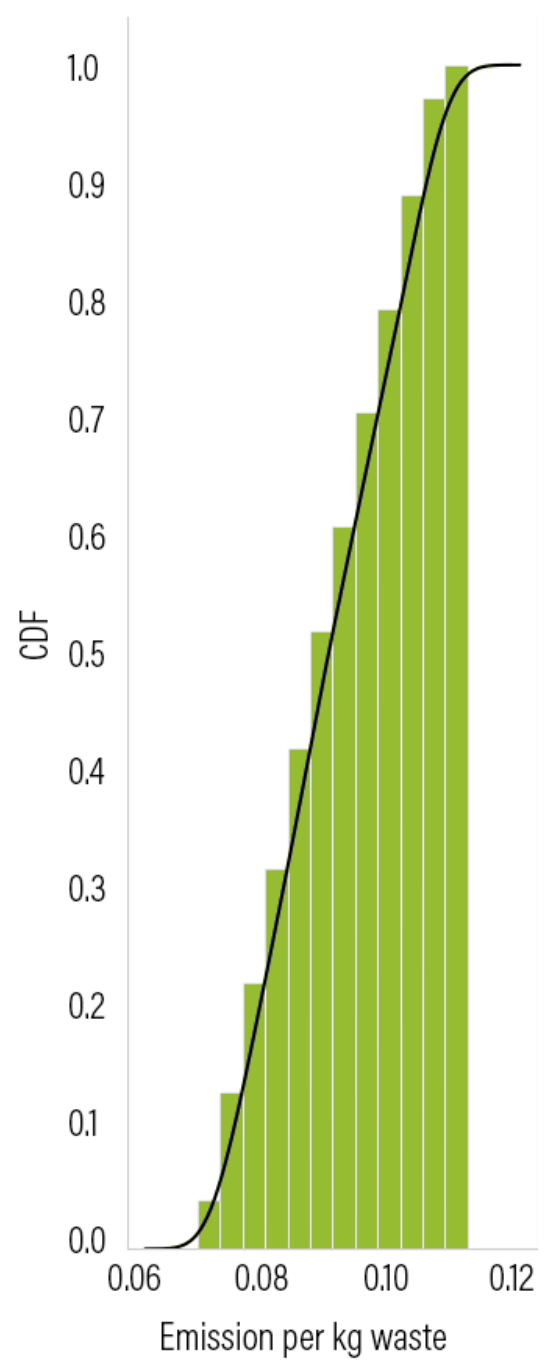

CDF for $\mathrm{N}_{2} \mathrm{O}$

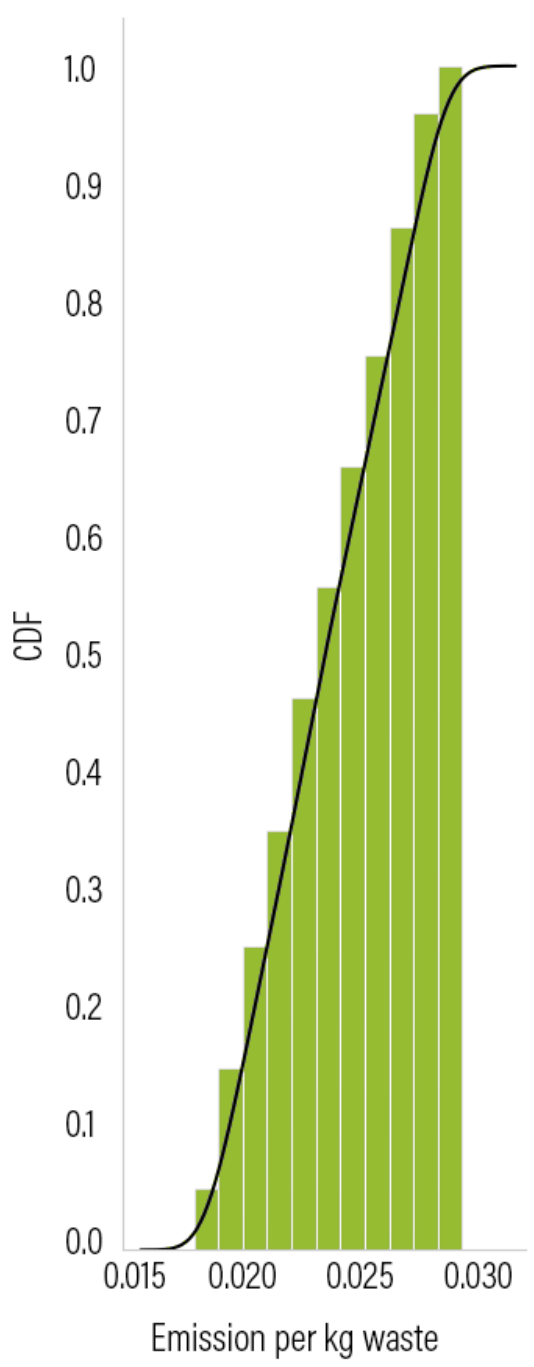

CDF for $\mathrm{CO}_{2}$

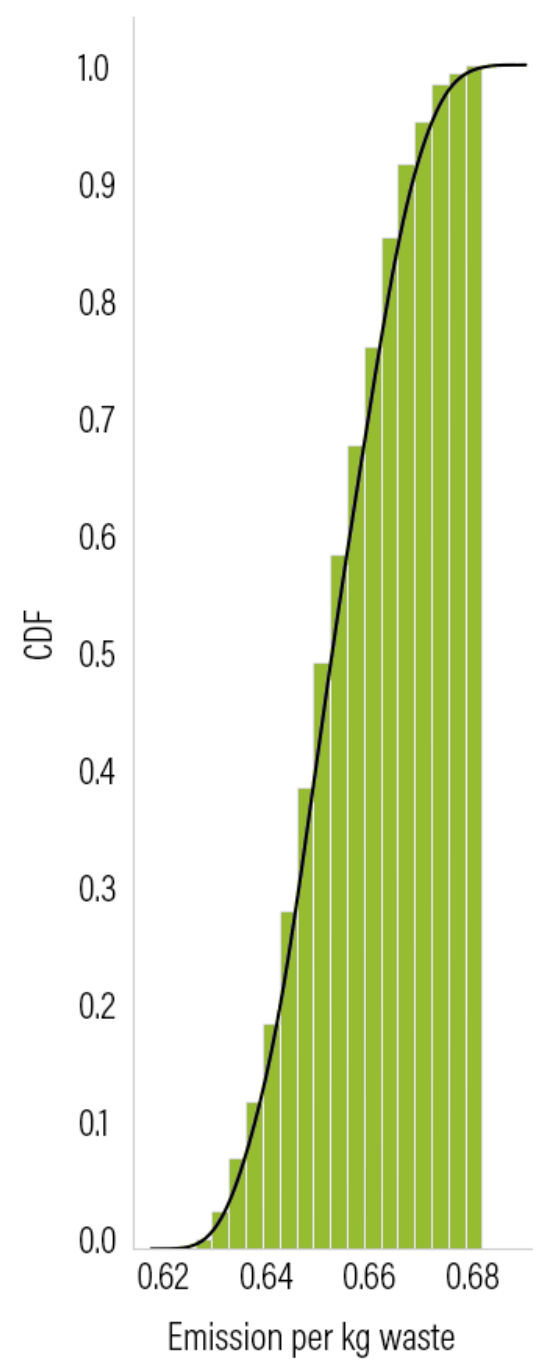


Figure A1 | Uncertainty Analysis CDF Plots for Rural Organic and Inorganic Waste (kg) Based on Waste Stream Data from Indonesia (2005) (Cont'd.)

CDF Plots for Rural Organic Waste

$\mathrm{CDF}$ for $\mathrm{CH}_{4}$

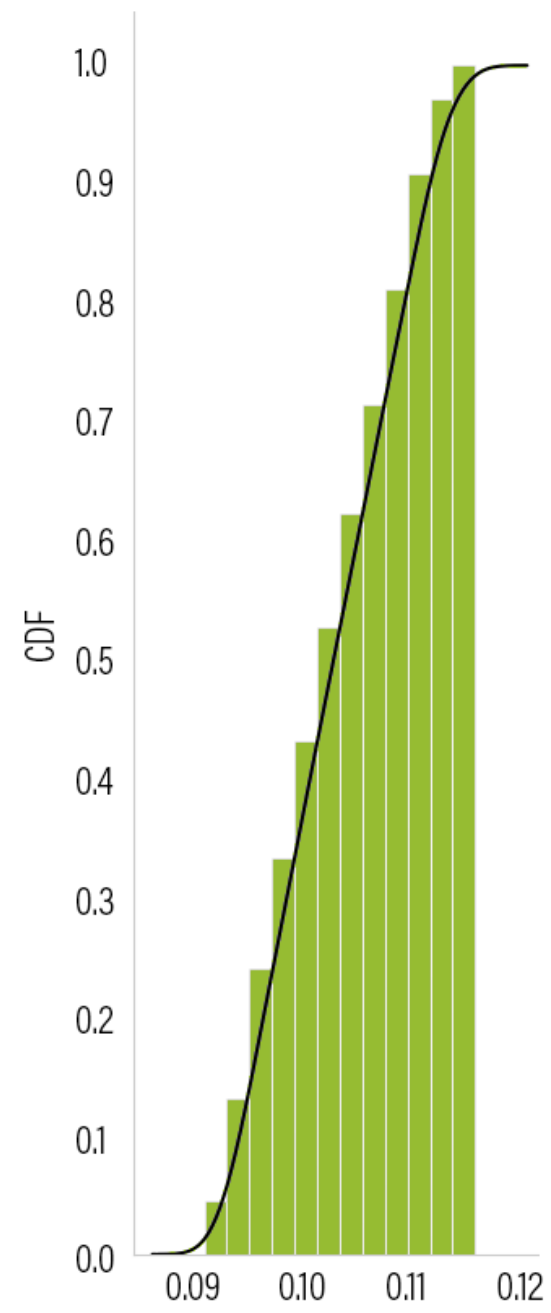

Emission per kg waste
CDF for $\mathrm{N}_{2} \mathrm{O}$

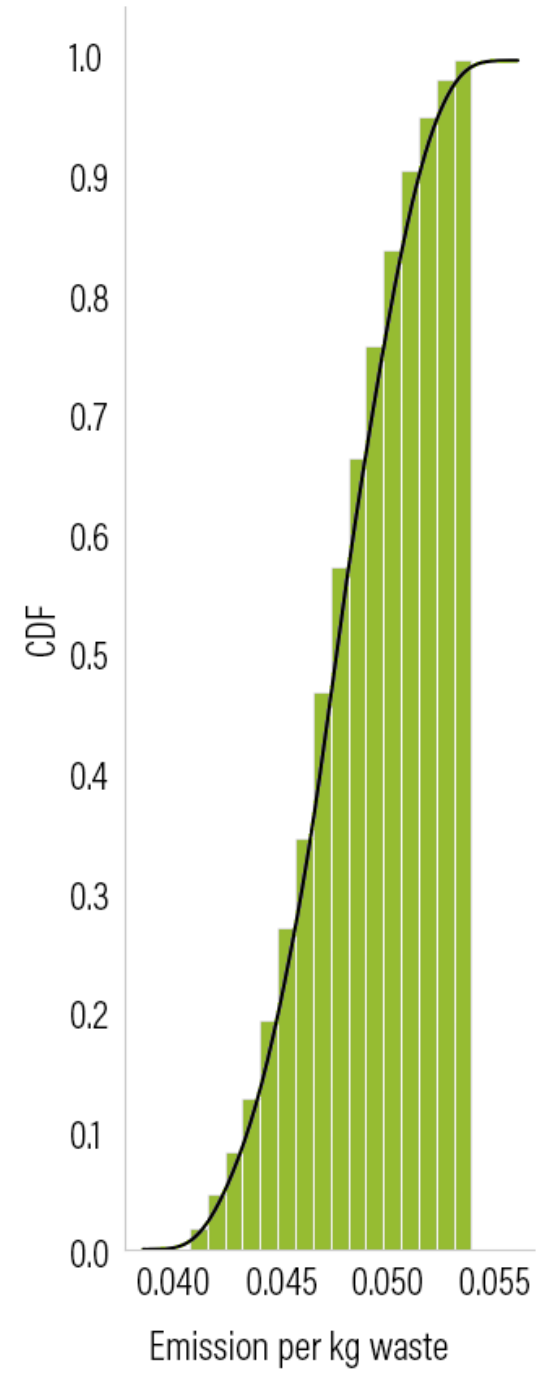

$\mathrm{CDF}$ for $\mathrm{CO}_{2}$

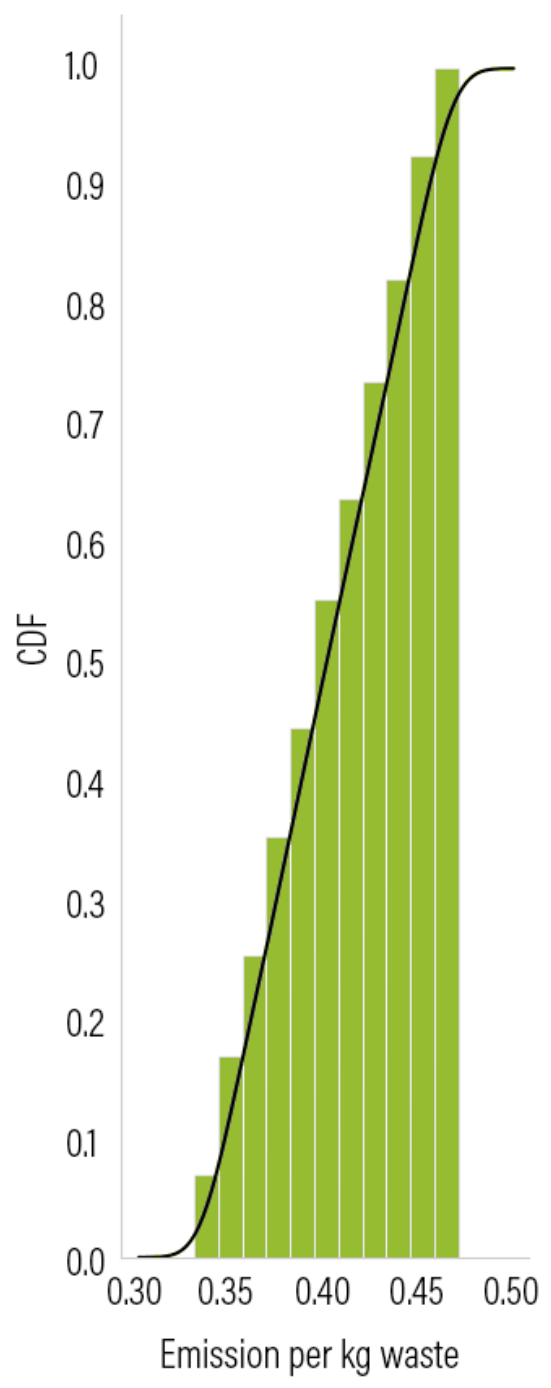


Figure A2 | Uncertainty Analysis CDF Plots for Urban Organic and Inorganic Waste (kg) Based on Waste Stream Data from Indonesia (2005)

CDF Plots for Urban Inorganic Waste

$\mathrm{CDF}$ for $\mathrm{CH}_{4}$

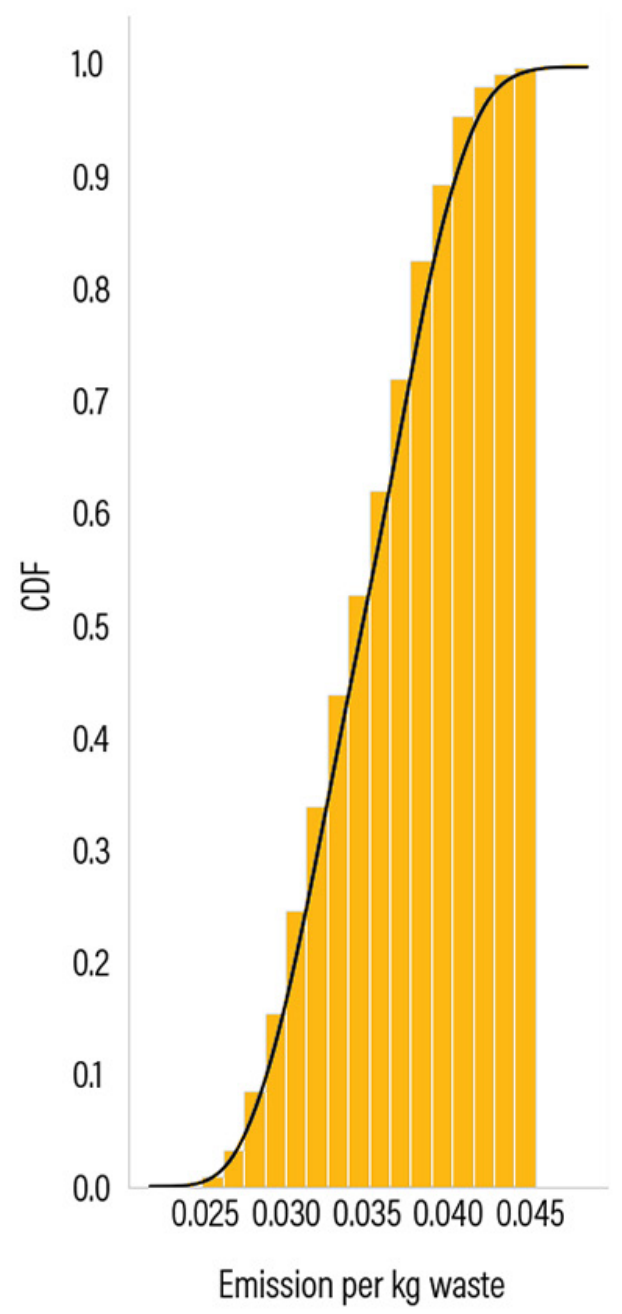

CDF for $\mathrm{N}_{2} \mathrm{O}$

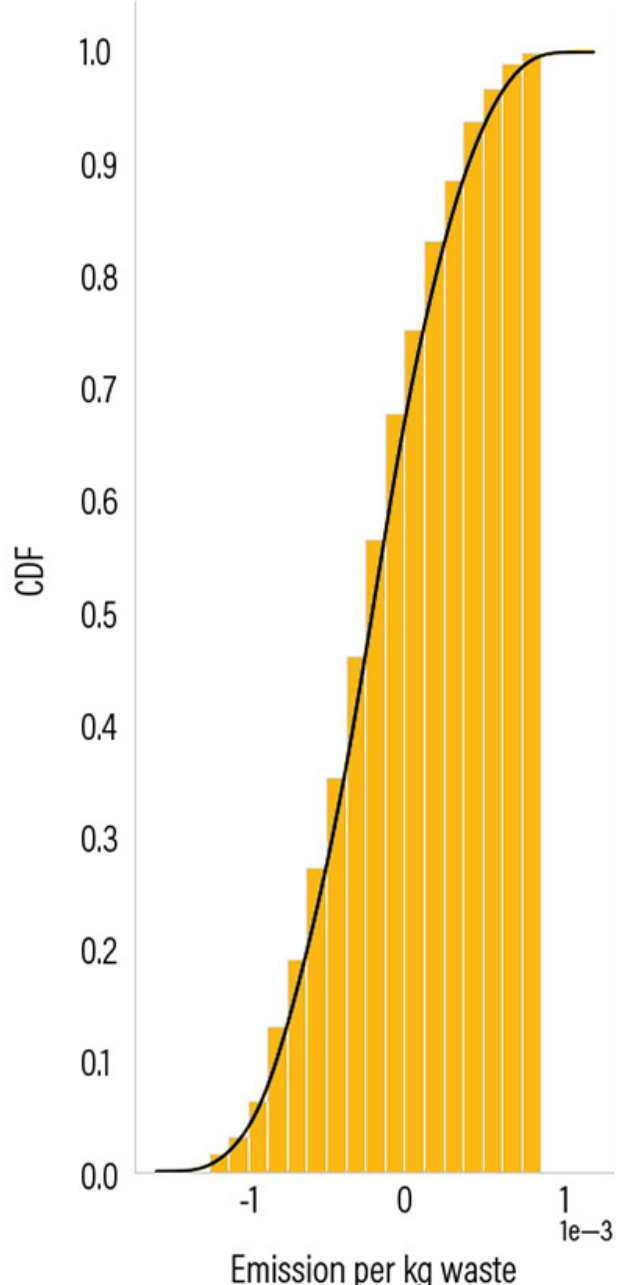

$\mathrm{CDF}$ for $\mathrm{CO}_{2}$

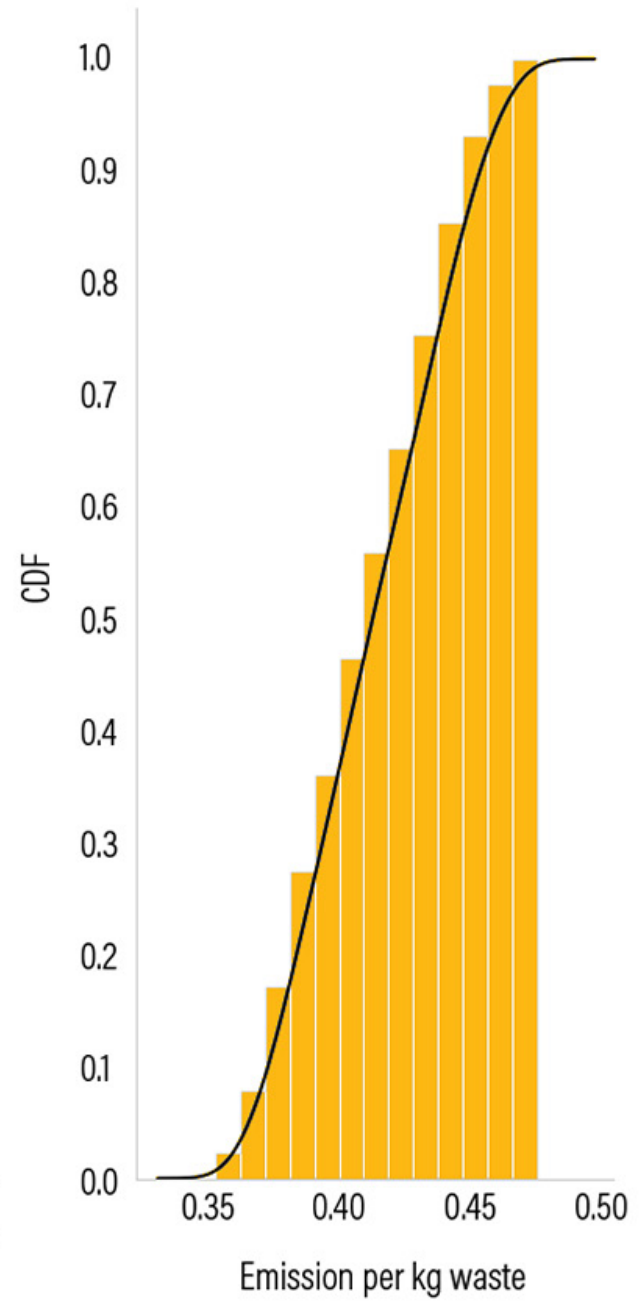


Figure A2 | Uncertainty Analysis CDF Plots for Urban Organic and Inorganic Waste (kg) Based on Waste Stream Data from Indonesia (2005) (Cont'd.)

CDF Plots for Urban Organic Waste

$\mathrm{CDF}$ for $\mathrm{CH}_{4}$

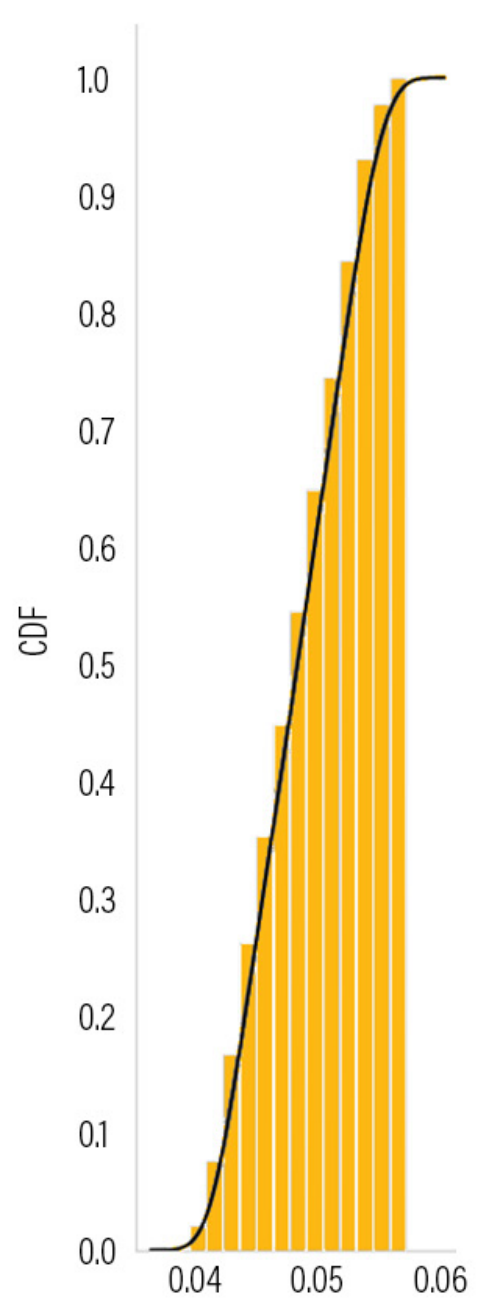

Emission per kg waste
CDF for $\mathrm{N}_{2} \mathrm{O}$

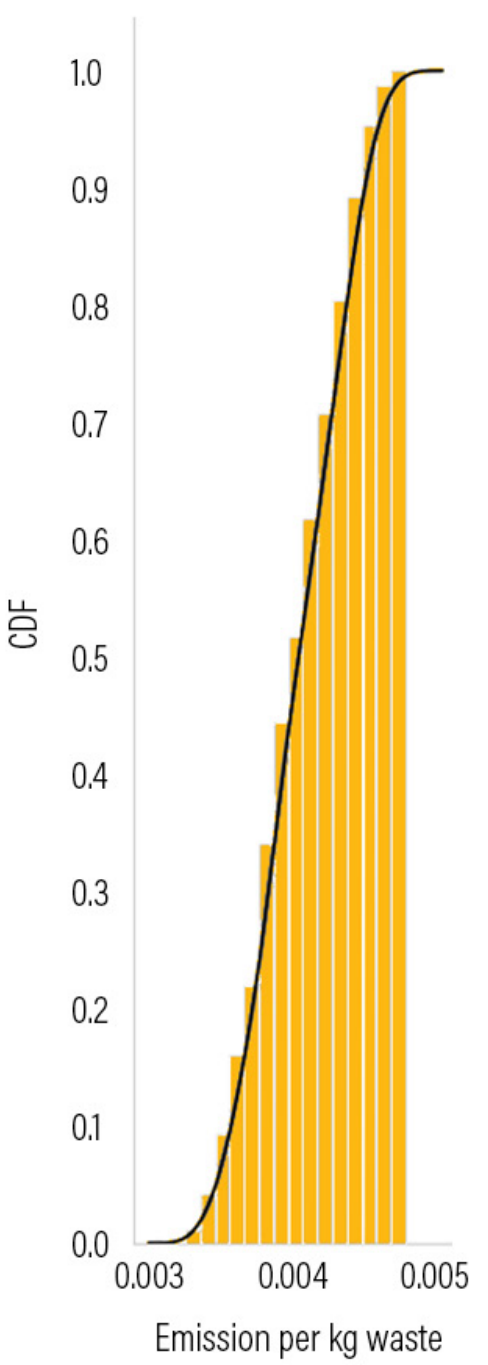

$\mathrm{CDF}$ for $\mathrm{CO}_{2}$

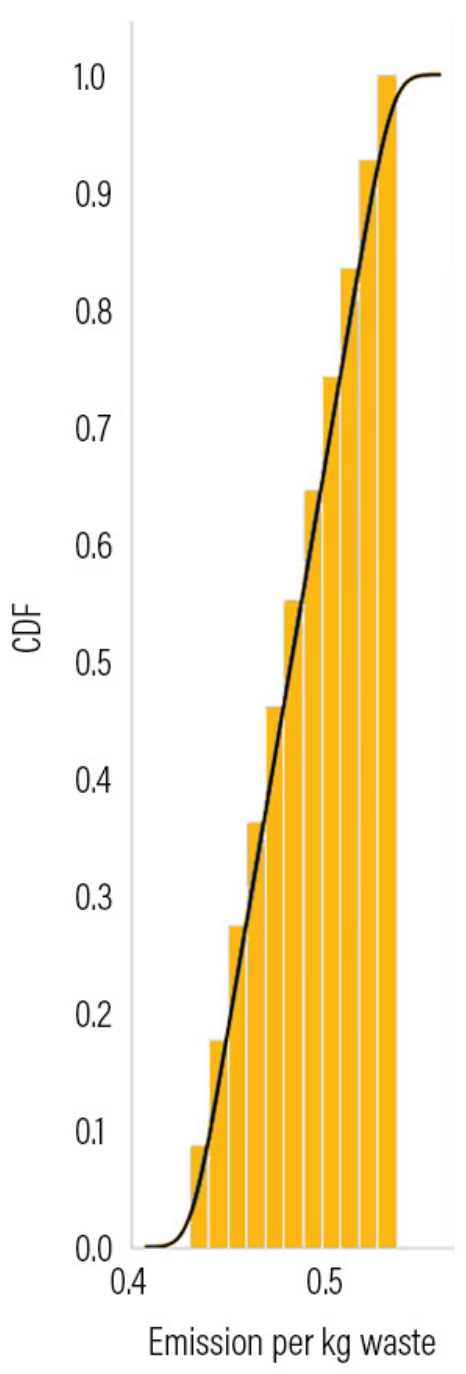




\section{ABBREVIATIONS}

AC air conditioning

CDF cumulative distribution function

CO carbon monoxide

$\mathrm{CO}_{2} \quad$ carbon dioxide

$\mathrm{CO}_{2} \mathrm{e} \quad$ carbon dioxide equivalent

$\mathrm{CH}_{4} \quad$ methane

EF emission factor

EIA Energy Information Administration

EMISI Indonesia Zero Emissions Application

EPA United States Environmental Protection Agency

GHG greenhouse gas

IEO Indonesia Energy Outlook

IPCC Intergovernmental Panel on Climate Change

ISO International Organization for Standardization

LCA Life Cycle Assessment

$\mathrm{LCl} \quad$ Life Cycle Inventory

LCIA Life Cycle Impact Assessment

LHS Latin Hypercube Sampling

LUC land use change

MoEF Ministry of Environment and Forestry

MoEMR Ministry of Energy and Mineral Resources

MSW municipal solid waste

$\mathrm{NO}_{\mathrm{x}} \quad$ nitrogen oxides

$\mathrm{N}_{2} \mathrm{O} \quad$ nitrous oxide

PP power plant

$\mathrm{SO}_{2} \quad$ sulfur dioxide

TCEP $_{p}$ total clothing emissions per person

TEEP $_{\mathrm{p}}$ total electricity emissions per person

TFEP $_{p}$ total food emissions per person

TWEP $_{p}$ total waste emissions per person

UNEP United Nations Environment Programme
1 Merriam-Webster defines fast fashion as "an approach to the design, creation, and marketing of clothing fashions that emphasizes making fashion trends quickly and cheaply available to consumers." (See MerriamWebster Unabridged, http://unabridged.merriam-webster.com/collegiate/ fast\%20fashion.) 
REFERENCES

Balogh, J.M., and A. Jámbor. 2020. "The Environmental Impacts of Agricultural Trade: A Systematic Literature Review." Sustainability 12 (3): 1152. https://doi. org/10.3390/su12031152.

Beton, A., D. Dias, L. Farrant, T. Gibon, and Y. Le Guern. 2014، Environmental Improvement Potential of Textiles. JRC Scientific and Technical Report. Luxembourg: Publications Office of the European Union.

Bulut, M. 2020. "Analysis of the Covid-19 Impact on Electricity Consumption and Production," Sakarya University Journal of Computer and Information Sciences 3 (3): 283-95. https://doi.org/10,35377/saucis.03.03.817595.

Carbon Neutral, n.d. "Carbon Calculator." https://carbonneutral.com.au/ carbon-calculatorl. Accessed May 18, 2021.

Cucurachi, S., L. Scherer, J. Guinée, and A. Tukker. 2019. "Life Cycle Assessment of Food Systems." One Earth 1 (3): 292-97. https://doi. org/10.1016/j,oneear.2019.10.014.

Curran, M.A. 2017. "Overview of Goal and Scope Definition in Life Cycle Assessment." In Goal and Scope Definition in Life Cycle Assessment, edited by M.A. Curran, 1-62. Dordrecht, Netherlands: Springer. https://doi. org/10,1007/978-94-024-0855-3 1.

DaftLogic. n.d. "List of the Power Consumption of Typical Household Appliances." https://www.daftlogic.com/information-appliance-powerconsumption.htm. Accessed May 18, 2021.

Damanhuri, E., W. Handoko, and T. Padmi. 2014. "Municipal Solid Waste Management in Indonesia." In Municipal Solid Waste Management in Asia and the Pacific Islands: Challenges and Strategic Solutions, edited by A. Pariatamby and M. Tanaka, 139-55. Singapore: Springer. https://doi. org/10.1007/978-981-4451-73-4 8 .

Damayanti, $R_{\text {, }}$ and $H$. Khaerunissa. 2018. "Carbon Dioxide Emission Factor Estimation from Indonesian Coal." Indonesian Mining Journal 21 (1): 45-58. https://doi.org/10.30556/imj,Vol21.No1.2018.687.

EIA (Energy Information Administration). 1999. Natural Gas 1998: Issues and Trends. Washington, DC: EIA. https://www.eia.gov/naturalgas/ archive/056098.pdf.

ENGIE. n.d. "How Does Gas-Fired Power Work?" https://engie.com.au/home/ engie-today/education/how-does-gas-fired-power-work/. Accessed May $18,2021$.

EPA (U.S. Environmental Protection Agency). 2015. "Greenhouse Gas Equivalencies Calculator." August 28. https://www.epa.gov/energy/ greenhouse-gas-equivalencies-calculator.

EPA. 2016. "Carbon Footprint Calculator." July 14. https://www3.epa.gov/ carbon-footprint-calculator.

EPA. 2020. "Direct Emissions from Stationary Combustion Sources." July 24. https://www.epa.gov/climateleadership/center-corporate-climateleadership-direct-emissions-stationary-combustion-sources.
FAO (Food and Agriculture Organization of the United Nations) and ICAC (International Cotton Advisory Committee). 2015. Measuring Sustainability in Cotton Farming Systems: Towards a Guidance Framework. Report prepared by the ICAC Expert Panel on Social, Environmental and Economic Performance of Cotton Production with the FAO Plant Production and Protection Division. Rome: FA0. http://www.fao.org/3/i4170e/i4170e.pdf.

Fong, W.K., M. Sotos, M. Doust, S. Schultz, A. Marques, and C. Deng-Beck. 2014. Global Protocol for Community-Scale Greenhouse Gas Emission Inventories: An Accounting and Reporting Standard for Cities. Washington, DC: Greenhouse Gas Protocol, World Resources Institute. https:// ghgprotocol.org/sites/default/files/standards/GHGP GPC 0.pdf.

Geoscience Australia, n.d. "Basics." https://www.ga.govaau/scientific-topics/ energy/basics. Accessed May 18, 2021.

Hertwich, E.G., and G.P. Peters. 2009. "Carbon Footprint of Nations: A Global, Trade-Linked Analysis." Environmental Science \& Technology 43 (16): 6414-20. https://doi.org/10.1021/es803496a.

Hilman, 0., and F. Harvey. 2019. "US Is Hotbed of Climate Change Denial, Major Global Survey Finds." The Guardian, May 8. https://www.theguardian. com/environment/2019/may/07/us-hotbed-climate-change-denialinternational-poll.

IFEU (Institut für Energie und Umweltforschung), J. Giegrich, and R. Vogt. 2009. SWM GHG Calculator: Tool for Calculating Greenhouse Gases (GHG) in Solid Waste Management (SWM). Frankfurt: KfW Bankengruppe.

IPCC (Intergovernmental Panel on Climate Change), 1991. Climate Change: The IPCC Scientific Assessment. Contribution of Working Group 1 to the First Assessment Report of the Intergovernmental Panel on Climate Change, edited by J.T. Houghton, G.J. Jenkins, and J.J. Ephraums. Cambridge and New York: Cambridge University Press. https://archive.ipcc.ch/ipccreports/far/ wg |/ipcc far wg I full report.pdf.

IPCC. 2006. 2006 IPCC Guidelines for National Greenhouse Gas Inventories, edited by S. Eggleston, L. Buendia, K. Miwa, T. Ngara, and K. Tanabe. 5 vols. Hayama, Japan: Institute for Global Environmental Strategies. https://www. ipcc-nggip.iges.or.jp/public/2006gl/.

ISO (International Organization for Standardization). 2018. IS0 14064-1:2018: Greenhouse Gases-Part 1: Specification with Guidance at the Organization Level for Quantification and Reporting of Greenhouse Gas Emissions and Removals, Geneva: ISO, https://www.iso.org/cms/render/live/en/sites/ isoorg/contents/data/standard/06/64/66453.html.

Kanoğlu, M., S. Kazım Ișık, and A. Abuşoğlu, 2005. "Performance Characteristics of a Diesel Engine Power Plant." Energy Conversion and Management 46 (11): 1692-702. https://doi.org/10.1016/j. enconman.2004.10.005.

Kristanto, G.A., and W. Koven. 2019. "Estimating Greenhouse Gas Emissions from Municipal Solid Waste Management in Depok, Indonesia." City and Environment Interactions 4 (December): 100027. https://doi.org/10.1016/j. cacint.2020.100027.

Maraver, D., A. Sin, J. Royo, and F. Sebastián. 2013. "Assessment of CCHP Systems Based on Biomass Combustion for Small-Scale Applications through a Review of the Technology and Analysis of Energy Efficiency Parameters." In Special Issue on Advances in Sustainable Biofuel Production and Use-XIX International Symposium on Alcohol Fuels-ISAF edited by J. Yan, G. Lidén, and D. Chiaramonti, Applied Energy 102 (February): 1303-13. https://doi.org/10.1016/i.apenergy.2012.07.012. 
McKay, M.D. 1992. "Latin Hypercube Sampling as a Tool in Uncertainty Analysis of Computer Models." In WSC '92: Proceedings of the 24th Conference on Winter Simulation, edited by J.J. Swain, D. Goldsman, R.C. Crain, and J.R. Wilson, 557-64. New York: Association for Computing Machinery. https://doi. org/10.1145/167293.167637.

Milosavljević, D.D., T.M. Pavlović, and D.S. Piršl. 2015. "Performance Analysis of a Grid-Connected Solar PV Plant in Niš, Republic of Serbia." Renewable and Sustainable Energy Reviews 44 (April): 423-35. https://doi.org/10.1016/j. rser.2014.12.031.

Ministry of National Development Planning. 2010. Indonesia Climate Change Sectoral Roadmap (ICCSR): Waste Sector. Jakarta: Ministry of National Development Planning, Republic of Indonesia. https://www. bappenas.go.id/files/8913/5022/6069/climate-change-roadmap-wastesector $20110218181950 \quad 0 . p d f$.

MoEMR (Ministry of Energy and Mineral Resources). 2020. Handbook of Energy \& Economic Statistics of Indonesia 2019, Jakarta: MoEMR, Republic of Indonesia. https://www.esdm.go.id/assets/media/content/content-handbookof-energy-and-economic-statistics-of-indonesia-2019.pdf

Moran, M.J., and H.N. Shapiro. 2010. Fundamentals of Engineering Thermodynamics. Singapore: Wiley.

National Energy Foundation. 2017. "Simple Carbon Calculator." http://www. carbon-calculator.org.uk/.

NEC (National Energy Council). 2019. Indonesia Energy Outlook 2019. Jakarta: National Energy Council, Republic of Indonesia. https://www.esdm.go.id/ assets/media/content/content-indonesia-energy-outlook-2019-englishversion.pdf.

O'Neill, B.C., M. Dalton, R. Fuchs, L. Jiang, S. Pachauri, and K. Zigova. 2010. "Global Demographic Trends and Future Carbon Emissions." Proceedings of the National Academy of Sciences of the United States of America 107 (41): 17521-26. https://doi.org/10.1073/pnas.1004581107.

Peters, G., M. Svanström, S. Roos, G. Sandin, and B. Zamani. 2015. "1-Carbon Footprints in the Textile Industry." In Handbook of Life Cycle Assessment (LCA) of Textiles and Clothing, edited by S.S. Muthu, 3-30. Cambridge, UK: Woodhead. https://doi.org/10.1016/B978-0-08-100169-1.00001-0,

PLN (Perusahaan Listrik Negara). 2017. Rencana Usaha Penyediaan Tenaga Listrik (RUPTL), http://web.pln.co.id/stakeholder/ruptl.

Poore, J., and T. Nemecek. 2018. "Reducing Food's Environmental Impacts through Producers and Consumers." Science 360 (6392): 987-92. https://doi. org/10.1126/science.aaq0216.

Quantis. 2018. Measuring Fashion: Insights from the Environmental Impact of the Global Apparel and Footwear Industries. Lausanne, Switzerland: Quantis. https://quantis-intl.com/wp-content/uploads/2018/03/measuringfashion globalimpactstudy full-report quantis cwf 2018a.pdf.

Rahman, D.F. 2021. "Indonesia's \$3.7b Food Delivery Market Largest in Region." Jakarta Post, January 28. https://www.thejakartapost.com/news/2021/01/28/ indonesias-3-7b-food-delivery-market-largest-in-region.html.
Remy, N., E. Speelman, and S. Swartz. 2016. Style That's Sustainable: A New Fast-Fashion Formula. New York: McKinsey. https://www.mckinsey. com/ /media/McKinsey/Business\%20Functions/Sustainability/Our\%20 Insights/Style\%20thats\%20sustainable\%20A\%20new\%20fast\%20 fashion\%20formula/Style-thats-sustainable-A-new-fast-fashion-formula-vF. pdf?shouldlndex=false.

Rizki, M., D.R. Sari, N.A. Noor, I. Basuki, R. Imanuddin, S. Damayanti, and N. Irwanto. 2020. "Indonesia Zero Emissions Application (EMISI): Methodologies for Calculating Urban Transport Emissions and Tree Sequestration." Technical Note. Jakarta: World Resources Institute Indonesia. https://wri-indonesia.org/en/publication/technical-note-emisi-app-urbantransport-tree.

Rogissart, L., C. Foucherot, and V. Bellassen. 2019. Estimating Greenhouse Gas Emissions from Food Consumption: Methods and Results. Paris: Institute for Climate Economics, https://www.i4ce.org/wp-core/wp-content/ uploads/2019/03/0318-14CE2984-EmissionsGES-et-conso-alimentaire-Note20p-VA V2.pdf.

Röös, E., C. Sundberg, and P.-A. Hansson. 2014. Carbon Footprint of Food Products." In Assessment of Carbon Footprint in Different Industrial Sectors, Volume 1, edited by S. Muthu, 85-112. Singapore: Springer. https://doi. org/10.1007/978-981-4560-41-2 4 .

Roy, P., D. Nei, T. Orikasa, Q. Xu, H. Okadome, N. Nakamura, and T. Shiina. 2009. "A Review of Life Cycle Assessment (LCA) on Some Food Products." Journal of Food Engineering 90 (1): 1-10. https://doi.org/10.1016/j. joodeng.2008.06.016.

Sadowski, M., C. Yan, C. Cummis, and N. Aden. 2019. Apparel and Footwear Sector Science-Based Targets Guidance. Washington, DC: World Resources Institute. https://www.wri.org/publication/apparel-and-footwear-sectorscience-based-targets-guidance.

Saidur, R., H.H. Masjuki, M.Y. Jamaluddin, and S. Ahmed. 2007. "Energy and Associated Greenhouse Gas Emissions from Household Appliances in Malaysia." Energy Policy 35 (3): 1648-57. https://doi.org/10,1016/i. enpol.2006.05.006.

Singh, V.K., and S.K. Singal. 2017. "Operation of Hydro Power Plants-a Review." Renewable and Sustainable Energy Reviews 69 (March): 610-19. https://doi.org/10,1016/j,rser.2016.11,169.

Unbound Solar, n.d. "Appliance Consumption Table." https://unboundsolar. com/solar-information/power-table. Accessed May 18, 2021.

UNEP (United Nations Environment Programme), 2020. "Improved Climate Action on Food Systems Can Deliver 20 Percent of Global Emissions Reductions Needed by 2050." Press Release, September 1. http://www. unep.org/news-and-stories/press-release/improved-climate-action-foodsystems-can-deliver-20-percent-global.

van der Velden, N.M., M.K. Patel, and J.G. Vogtländer. 2014. "LCA Benchmarking Study on Textiles Made of Cotton, Polyester, Nylon, Acryl, or Elastane." International Journal of Life Cycle Assessment 19 (2): 331-56. https://doi.org/10.1007/s11367-013-0626-9.

Wijaya, M.E, and T. Tezuka. 2013. "A Comparative Study of Households' Electricity Consumption Characteristics in Indonesia: A Technosocioeconomic Analysis." Energy for Sustainable Development 17 (6): 596-604. https://doi.org/10.1016/j.esd.2013.09.004. 


\section{ACKNOWLEDGMENTS}

We are pleased to acknowledge our various institutional strategic partners who provide core funding to the World Resources Institute (WRI). Their bilateral funding for projects made this publication possible.

The authors would like to thank the following people for providing invaluable insight and assistance in the development of this paper: Dean Affandi (WRI Indonesia), Emilia Suarez (WRI), and Gregory Taff (WRI).

We also thank our internal and external reviewers, Eve Mcdonald-Madden (University of Queensland), Seny Damayanti (Institut Teknologi Bandung), David Silalahi (Australia National University), Aline Nolasco Escalona (WRI), Brian Lipinski (WRI), Lucas Toh (WRI), Nate Aden (WRI), Priya J Shah (WRI), and Stacy Blondin (WRI).

The authors would also like to thank Sakinah Haniy, Romain Warnault, Lauri Scherer, Farhan Fahrezi, Septika Sihite, and Aulia Lastriarsi for their extensive support during the editing and design of this study. Opinions or points of view expressed in this report are those of the authors and do not necessarily reflect the position of the reviewers and our partners.

\section{ABOUT THE AUTHORS}

\section{Dewi R. Sari}

Sustainability Analyst, WRI Indonesia dewi.sari@wri.org

\section{Muhamad Rizk}

Mobility and Transport Specialist, WRI Indonesia

Lecturer, Civil Engineering Department,

Institut Teknologi Nasional Bandung

muhamad.rizki@wriorg

\section{Benita Nathania}

Research Analyst for Sustainable Commodities, WRI Indonesia benita.nathania@wriorg

\section{Mumtaz Ahmad}

Climate Finance, Accounting \& Risk Specialist, WRI Indonesia mumtaz.ahmad@wri.org

\section{Philipe G. Gan}

Former Data Scientist Intern, WRI Indonesia PhD Candidate, Australian National University philipe.gunawan@anu.edu.au

\section{Nanda A. Noor}

Sustainable Landscape \& Business Senior Lead, WRI Indonesia nanda.noor@wri.org
World Resources Institute is a global research organization that turns big ideas into action at the nexus of environment, economic opportunity, and human well-being.

\section{Our Challenge}

Natural resources are at the foundation of economic opportunity and human well-being. But today, we are depleting Earth's resources at rates that are not sustainable, endangering economies and people's lives. People depend on clean water, fertile land, healthy forests, and a stable climate. Livable cities and clean energy are essential for a sustainable planet. We must address these urgent, global challenges this decade.

\section{Our Vision}

We envision an equitable and prosperous planet driven by the wise management of natural resources. We aspire to create a world where the actions of government, business, and communities combine to eliminate poverty and sustain the natural environment for all people.

\section{Our Approach}

COUNT IT

We start with data. We conduct independent research and draw on the latest technology to develop new insights and recommendations. Our rigorous analysis identifies risks, unveils opportunities, and informs smart strategies. We focus our efforts on influential and emerging economies where the future of sustainability will be determined.

\section{CHANGE IT}

We use our research to influence government policies, business strategies, and civil society action. We test projects with communities, companies, and government agencies to build a strong evidence base. Then, we work with partners to deliver change on the ground that alleviates poverty and strengthens society. We hold ourselves accountable to ensure our outcomes will be bold and enduring.

\section{SCALE IT}

We don't think small. Once tested, we work with partners to adopt and expand our efforts regionally and globally. We engage with decision-makers to carry out our ideas and elevate our impact. We measure success through government and business actions that improve people's lives and sustain a healthy environment.

Maps are for illustrative purposes and do not imply the expression of any opinion on the part of WRI concerning the legal status of any country or territory or concerning the delimitation of frontiers or boundaries. 